\title{
Interfacial Phenomena and Inclusion Formation Behavior at Early Melting Stages of HCFeCr and LCFeCr Alloys in Liquid Iron
}

\author{
YONG WANG (D, ANDREY KARASEV, JOO HYUN PARK, WANGZHONG MU (D, \\ and PÄR G. JÖNSSON
}

\begin{abstract}
Chromium is normally added to liquid alloy in the form of different grades of ferrochromium $(\mathrm{FeCr})$ alloys for the requirement of different alloy grades, such as stainless steels, high $\mathrm{Cr}$ cast iron, etc.. In this work, inclusions in two commercially produced alloys, i.e., high-carbon ferrochromium $(\mathrm{HCFeCr})$ and low-carbon ferrochromium ( $\mathrm{LCFeCr}$ ) alloys, were investigated. The $\mathrm{FeCr}$ alloy/liquid iron interactions at an early stage were investigated by inserting solid alloy piece into contact with the liquid iron for a predetermined time using the liquid-metal-suction method. After quenching these samples, a diffusion zone between the alloys and the liquid $\mathrm{Fe}$ was studied based on the microstructural characterizations. It was observed that $\mathrm{Cr}-\mathrm{O}-(\mathrm{Fe})$ inclusions were formed in the diffusion zone, $\mathrm{FeO}_{x}$ inclusions were formed in the bulk Fe, and an "inclusion-free" zone was detected between them. Moreover, it was found that the $\mathrm{HCFeCr}$ was slowly dissolved, but $\mathrm{LCFeCr}$ alloy was rapidly melted during the experiment. The dissolution and melting behaviors of these two $\mathrm{FeCr}$ alloys were compared and the mechanism of the early-stage dissolution process of $\mathrm{FeCr}$ alloys in the liquid $\mathrm{Fe}$ was proposed.
\end{abstract}

https://doi.org/10.1007/s11663-021-02185-8

(C) The Author(s) 2021

\section{INTRODUCTION}

CHROMIUM (Cr) is one of the vital importance alloying element in the steelmaking process since it enhances the hardness, hardenability, corrosion, abrasion, and wear resistance of the final product. ${ }^{[1]} \mathrm{The} \mathrm{Cr}$ in liquid steel is usually added in the form of ferrochromium $(\mathrm{FeCr})$ alloys. Different grades of $\mathrm{FeCr}$ alloys are selected for the alloying process according to the carbon content requirement of the final product, i.e., high-carbon ferrochromium $(\mathrm{HCFeCr}, 4$ to 8 mass pct $\mathrm{C})$, medium-carbon ferrochrome ( $\mathrm{MCFeCr} 0.5$ to 4 mass pet C), and low-carbon ferrochromium (LCFeCr, $<0.5$ mass pct C) alloys. ${ }^{[2]}$ These $\mathrm{FeCr}$ grades differ not only in their $\mathrm{C}$ content but also impurities present owing to their different manufacturing routes. It

YONG WANG, ANDREY KARASEV, WANGZHONG MU and PÄR G. JÖNSSON are with the Department of Materials Science and Engineering, KTH Royal Institute of Technology, Stockholm 100 44, Sweden. Contact e-mails: yongwang@kth.se,wmu@kth.se JOO HYUN PARK is with the Department of Materials Science and Engineering, KTH Royal Institute of Technology and also with the Department of Materials Engineering, Hanyang University, Ansan 15588, Korea.

Manuscript Submitted on January 6, 2021, Accepted April 7, 2021.

Article published online May 18, 2021. is known that the addition of ferroalloys resulting in a supply of additional inclusions in the steels. ${ }^{[3]}$ Therefore, it is extremely important to determine the inclusion characteristics in ferroalloys to meet the increasing demand for strict inclusion control of clean steel concept.

An important factor that should be focused on is the yield ratio of the alloying element after the ferrous alloys addition process. This can be significantly influenced by the interactions between the ferroalloys and the liquid iron or steel. ${ }^{[4]}$ Therefore, thorough knowledge of the dissolution behavior of alloying agents is required to control the alloying process precisely. Furthermore, it is important to know the kinetics of the added alloying agents dissolve in the liquid steel because the dissolution behavior influences the homogeneity of the melt, as well as inclusion formations and transformations. ${ }^{[5]}$ Several researchers have investigated the early stage dissolution behavior of different ferroalloys. ${ }^{[4,6-9]}$ However, not enough attention has been paid to the interfacial processes between $\mathrm{FeCr}$ alloys and liquid iron and steel so far. In stainless steelmaking process, comparatively cheap $\mathrm{HCFeCr}$ alloys are added initially before decarburization. However, for the final adjustments of the steel composition, it is necessary to have low-carbon contents in the added ferroalloys, especially by production of low $\mathrm{C}$ high alloy steels. Thus, more expensive 
LCFeCr alloys are usually used. Furthermore, it is known that the $\mathrm{C}$ content can have great influence on the dissolution and melting behavior of ferroalloys. Besides, the actual dissolution path differs depending on the physical properties of the alloys, such as the density and the melting point. Therefore, the comparison of the dissolution behaviors of $\mathrm{HCFeCr}$ and $\mathrm{LCFeCr}$ alloys in the Fe melt is worth to be investigated.

During the alloy dissolution process, the inclusion formation in some local areas having higher concentrations of alloying elements and the motion behavior of existing inclusions from the alloys after the alloy melting are also interesting to know. Previous studies ${ }^{[10-12]}$ have reported that many different types of inclusions existed in $\mathrm{HCFeCr}$ and $\mathrm{LCFeCr}$ alloys. The presence of inclusions is directly related to the ferroalloy production route. Thus, a study of the inclusions in these alloys is beneficial for optimization of the production technology to avoid the generation of detrimental inclusions. It is known that more than 90 pet of these $\mathrm{FeCr}$ alloys are used in the production of stainless steels. ${ }^{[13]}$ Numerous studies have focused on the formation and control of inclusions and the influence of inclusions on the mechanical properties of stainless steels. ${ }^{[14,15]}$ However, for the behavior of inclusions from $\mathrm{FeCr}$ alloys in the steel melt after alloying, a gap for the understanding still exists. Apparently, some local zones in the liquid steel surrounding the added pieces of $\mathrm{FeCr}$ alloy have higher concentrations of $\mathrm{Cr}$ right after the alloying process. Especially, to the author's knowledge, the formation of new inclusions in this local zone of the liquid melt during the initial stage has not been reported much.
In this study, the characteristics of different inclusions in commercial $\mathrm{HCFeCr}$ and $\mathrm{LCFeCr}$ alloys were analyzed. The interactions between $\mathrm{FeCr}$ and liquid $\mathrm{Fe}$ shortly after the alloy additions in the early stage were investigated in quenched samples, which were obtained by contacting the solid alloy with liquid $\mathrm{Fe}$ for several seconds. The interactions, i.e., melting of the ferroalloys, diffusion of chemical elements, the nucleation, and growth of inclusions were investigated for the cases of these two alloys additions. The focus is to understand the initial dissolution phenomenon of $\mathrm{FeCr}$ alloys in the liquid $\mathrm{Fe}$ as well as the behavior of inclusion formations at the early stages of $\mathrm{FeCr}$ alloying.

\section{EXPERIMENTAL}

\section{A. Procedure}

The liquid-metal-suction method was used to investigate the early stage of the dissolution behavior of $\mathrm{HCFeCr}$ and $\mathrm{LCFeCr}$ alloys in liquid Fe. The chemical compositions of these two commercial alloys are given in Table I. $500 \mathrm{~g}$ of electrolytic iron (99.9 mass pct Fe) was melted in a magnesia crucible which was placed inside a graphite crucible in a medium frequency induction furnace. A schematic illustration of the experimental setup is shown in Figure 1(a). Details of the instrumentation as well as the setup of this furnace have been reported elsewhere. ${ }^{[16]}$ Initially, a small piece of $\mathrm{FeCr}$ alloy $(0.5 \mathrm{~g})$ was placed in a quartz tube $(6 \mathrm{~mm}$ inside diameter) with a small hole in the bottom end

Table I. Main Chemical Compositions of HCFeCr and LCFeCr Alloys (Mass Percent)

\begin{tabular}{lccccccccccccc}
\hline Element & $\mathrm{Cr}$ & $\mathrm{Si}$ & $\mathrm{Mn}$ & $\mathrm{C}$ & $\mathrm{Al}$ & $\mathrm{Ca}$ & $\mathrm{Ni}$ & $\mathrm{Ti}$ & $\mathrm{N}$ & $\mathrm{O}$ & $\mathrm{S}$ & $\mathrm{P}$ & $\mathrm{Fe}$ \\
\hline $\mathrm{HCFeCr}$ & 66.3 & 0.50 & 0.07 & 8.2 & 0.02 & 0.03 & 0.25 & 0.28 & 0.043 & 0.031 & 0.032 & 0.023 & balance \\
LCFeCr & 71.8 & 0.41 & 0.25 & 0.03 & 0.05 & 0.04 & 0.14 & 0.12 & 0.021 & 0.078 & 0.002 & 0.009 & balance \\
\hline
\end{tabular}

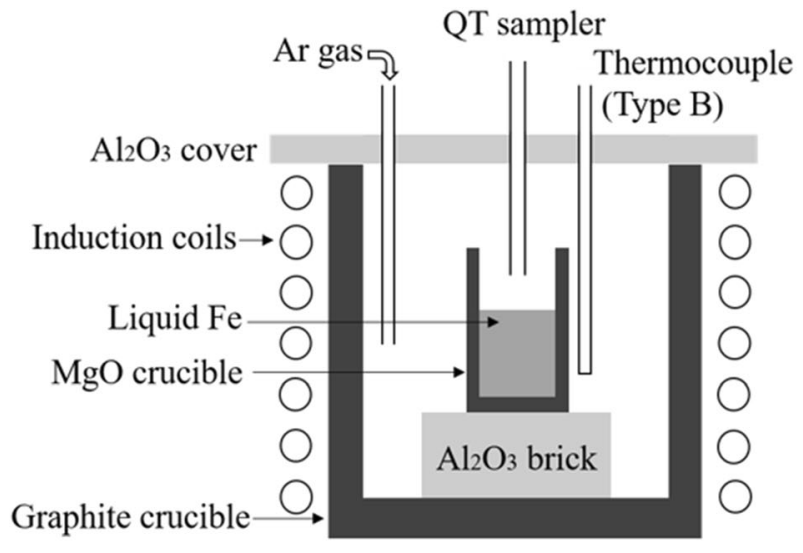

(a)

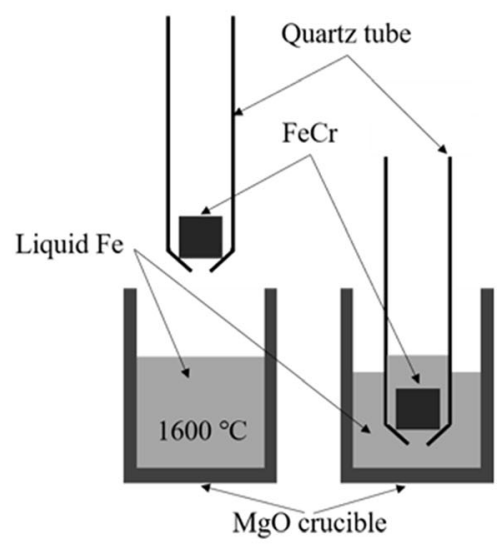

(b)

Fig. 1-Schematic illustration of the (a) experimental setup and (b) sampling procedure. 
(1.5 mm diameter) before sampling (Figure 1(b)). After the temperature reached $1873 \mathrm{~K}\left(1600{ }^{\circ} \mathrm{C}\right)$, the iron melt was homogenized for 30 minutes under an argon atmosphere. Subsequently, samples from the melt were taken by quartz tubes (QT samples) where a small volume of liquid $\mathrm{Fe}$ was sucked up through the tube and brought into contact with the alloy piece. After the $\mathrm{FeCr}$ piece was held in the melt for the desired time of 5, 10, 20 , and 30 seconds, the quartz tube sample was rapidly withdrawn from the furnace and quenched in the water of room temperature. The schematic illustration for the samplings is listed in Figure 2.

\section{B. Analysis and Characterization}

The inclusion characteristics in polished $\mathrm{HCFeCr}$ and $\mathrm{LCFeCr}$ samples were analyzed using a scanning electron microscope (SEM, S3700N-Hitachi, Hitachi High-Technologies Corporation, Japan) equipped with an energy dispersive spectrometer (EDS, Bruker, Germany). The vertical central cross-section of the upper part of QT samples contained $\mathrm{HCFeCr}$ piece was polished and subjected to microstructure and inclusion investigations using EDS. In addition, to better understand the inclusion characteristics in different regions at the interface between the alloy and $\mathrm{Fe}$, the polished surfaces of the specimens were shortly etched using a 10 pct AA electrolyte (10 pct acetylacetone- 1 pct tetramethylammonium chloride-methanol) at the following parameters: electric charge- 100 coulombs, 60 to $62 \mathrm{~mA}$ and $3.4 \mathrm{~V}$. Thereafter, the etched surfaces of these specimens were observed using an SEM-EDS for inclusion analysis.

In terms of the QT samples with LCFeCr alloy, the location of the alloy piece cannot be directly observed. Therefore, each QT sample was cut into five parts of equal length $(20 \mathrm{~mm})$ and then polished to find the accurate location of the alloys.

The average size of inclusions, $d_{\mathrm{A}}$, was calculated according to Eq. [1]:

$$
d_{A}=\frac{L_{\max }+W_{\max }}{2}
$$

where $L_{\max }$ and $W_{\max }$ are the maximum length and width of the investigated inclusion, which were measured by software ImageJ. The number of inclusions per unit area $\left(N_{\mathrm{A}}\right)$ and area fraction $\left(f_{s}\right)$ of inclusions were estimated by Eqs. [2] and [3]

$$
\begin{gathered}
N l A=\frac{n_{\text {total }}}{A} \\
f_{s}=\frac{\sum_{i=1}^{n} A_{i}}{A}
\end{gathered}
$$

where $n_{\text {total }}$ is the total number of inclusions observed on a polished metal surface, $A$ is the total observed area on a polished metal surface and $A_{i}$ is the area of the $i$-th inclusion.

The floatation behavior of inclusions in the melt was estimated using the Stoke's law, ${ }^{[17]}$ which is expressed by Eq. [4]:

$$
D=\frac{\rho_{\mathrm{Fe}} \rho_{\text {inclusions }}}{18 \mu} \cdot g \cdot d^{2} \cdot t
$$

where $D$ is the floatation distance, $g$ is the gravitational acceleration $\left(9.81 \mathrm{~m} \cdot \mathrm{s}^{-2}\right), t$ is the dynamic viscosity of liquid steel $(0.005 \mathrm{~m} \mathrm{~Pa} \mathrm{~s}),{ }^{[18]} d$ is the diameter of the spherical inclusion, $t$ is the floatation time and, $\rho_{\mathrm{Fe}}$ and $\rho_{\text {inclusions }}$ are the densities of liquid $\mathrm{Fe}\left(\sim 6980 \mathrm{~kg} \mathrm{~m}^{-3}\right)$ and inclusion, respectively. The density of $\mathrm{MnCr}_{2} \mathrm{O}_{4}$ and $\mathrm{FeCr}_{2} \mathrm{O}_{4}$ are taken as $4930 \mathrm{~kg} \mathrm{~m}^{-3[11]}$ and $4700 \mathrm{~kg} \mathrm{~m}^{-3}$, ${ }^{[19]}$ respectively. For applying the equation, it is assumed that the fluid flow of the melt is negligible.

\section{RESULTS AND DISCUSSION}

\section{A. Inclusions in $\mathrm{HCFeCr}$ and $\mathrm{LCFeCr}$ Alloys}

The characteristics of inclusions in $\mathrm{HCFeCr}$ alloys are presented in Table II. The majority of the inclusions $(\sim 54 \mathrm{pct})$ existed in $\mathrm{HCFeCr}$ alloys is sulfide, which contains a composition close to the stoichiometric phase $2 \mathrm{CrS} \cdot \mathrm{MnS}$ (type A1) and pure CrS (type A2). The melting points of $2 \mathrm{CrS} \cdot \mathrm{MnS}$ and $\mathrm{CrS}$ are about $1723 \mathrm{~K}$ $\left(1450{ }^{\circ} \mathrm{C}\right)$ and $1838 \mathrm{~K}\left(1565^{\circ} \mathrm{C}\right)$ according to the MnS-CrS phase diagram. ${ }^{[20]}$ Besides, the size range of type A1 inclusions is significantly larger compared to that of type A2 inclusions. The percentage of type B

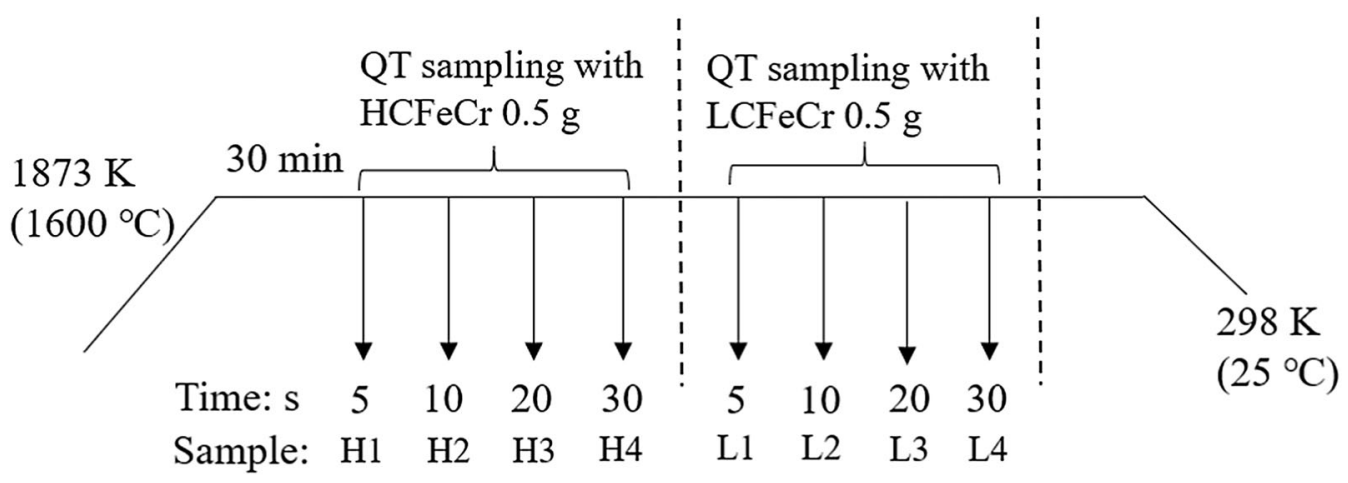

Fig. 2-Schematic illustration of the main operations and samplings during the experiment. 
Table II. Classification of Typical Inclusions Observed in HCFeCr Alloys
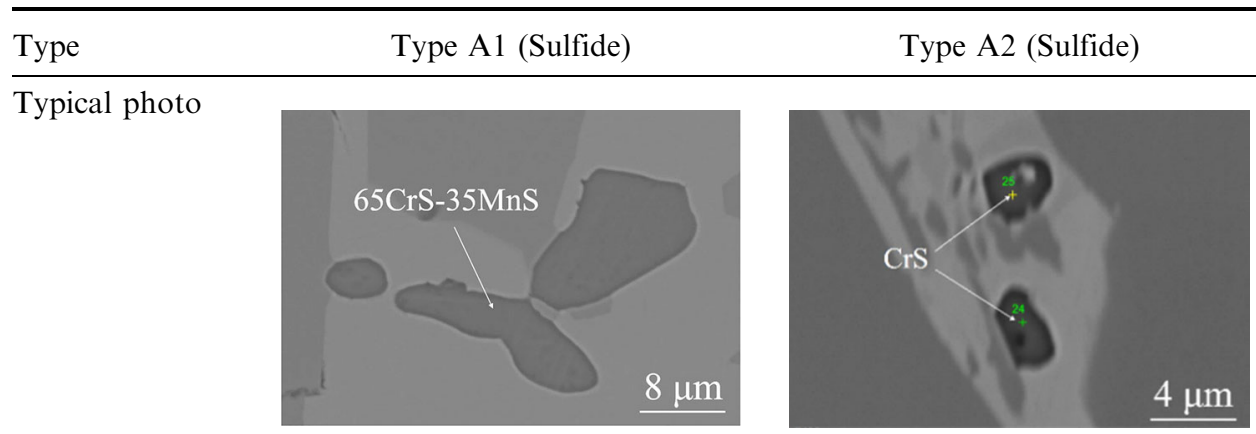

Type B (Oxide + Nitride)

Size range, $(\mu \mathrm{m})$

1.5 to 23.1

1.1 to 5.3

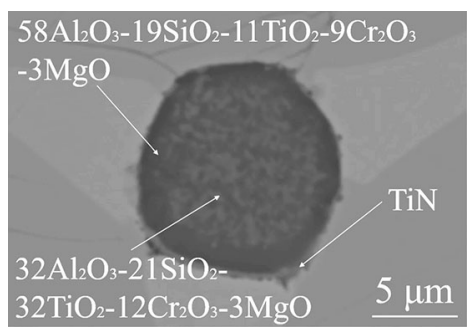

Frequency (pct)

54

3.3 to 16.1

21

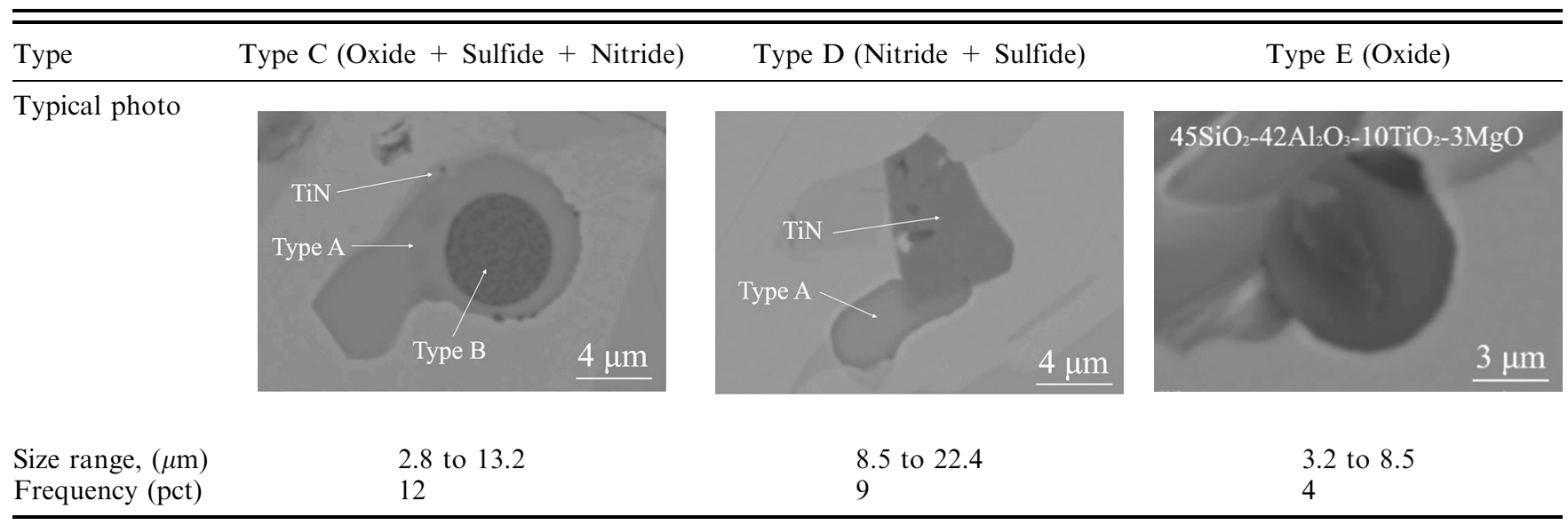

Table III. Classification of Typical Inclusions Observed in LCFeCr Alloys

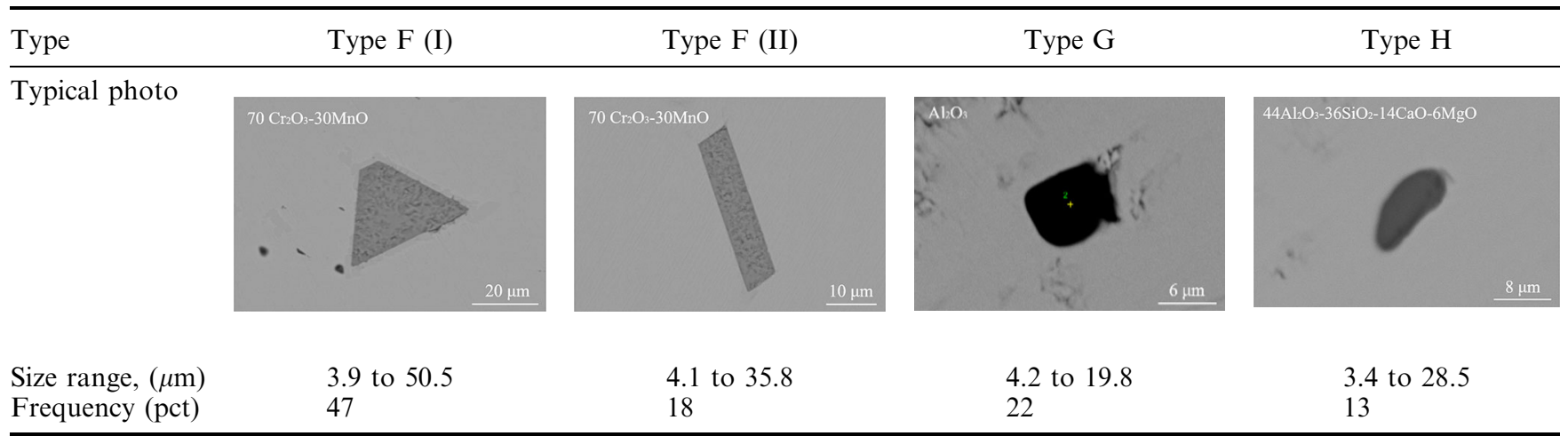

inclusions ranks the second place $(\sim 21 \mathrm{pct})$, which are complex spherical oxides (Al-Si-Ti-Cr-Mg-O) with small precipitation of TiN on the surface of these inclusions. The melting temperature of the oxide inclusions is about $1653 \mathrm{~K}$ to $1743 \mathrm{~K}\left(1380{ }^{\circ} \mathrm{C}\right.$ to $\left.1470{ }^{\circ} \mathrm{C}\right)$. More specifically, the core consists of a gray phase with higher $\mathrm{TiO}_{x}$ content and a dark phase having higher $\mathrm{Al}_{2} \mathrm{O}_{3}$ content. The third type $\mathrm{C}$ group $(\sim 12 \mathrm{pct})$ contains more complex inclusions, which consist of an oxide inclusion (same as type B) in the inner part and a sulfide inclusion (same as type A) in the outer part. The formation of the sulfide surrounding the oxide is due to the complex oxide serve as an effective nucleation site to reduce the energy for the sulfide formation. Type D inclusions contain pure TiN inclusions and complex sulfide (type A) inclusions. Finally, type E inclusions are complex Si-Al-Ti-Mg-O oxides (melting temperature is about $1597 \mathrm{~K}$ to $1655 \mathrm{~K}\left(1324{ }^{\circ} \mathrm{C}\right.$ to $\left.1382{ }^{\circ} \mathrm{C}\right)$ according to FactSage calculation, which form as a liquid state at the steelmaking temperature. 
The characteristics of inclusions in $\mathrm{LCFeCr}$ alloys are presented in Table III. Overall, three types of inclusions exist in $\mathrm{LCFeCr}$ alloys. The main inclusion type is $\mathrm{MnCr}_{2} \mathrm{O}_{4}$ spinel inclusions ( $65 \mathrm{pct}$ ), which have a high melting point of about $2373 \mathrm{~K}\left(2100{ }^{\circ} \mathrm{C}\right) .{ }^{[21]}$ According to the morphology, they could further be divided into two groups: polygonal type F (I) and bar-like type F (II). The percentage of type F (I) inclusions is about 2.5 times larger than that of type F (II) inclusions. Also, the size range of type $\mathrm{F}$ (I) inclusions (3.9 to $50.5 \mu \mathrm{m}$ ) is significantly wider compared to type F (II) inclusions (4.1 to $35.8 \mu \mathrm{m})$. The second group $(\sim 22 \mathrm{pct})$ is irregular $\mathrm{Al}_{2} \mathrm{O}_{3}$ inclusions (type $\mathrm{G}$ ). Previously it has been reported that $\mathrm{MnCr}_{2} \mathrm{O}_{4}$ and $\mathrm{Al}_{2} \mathrm{O}_{3}$ inclusions were considered as harmful inclusions in the $\mathrm{LCFeCr}$ alloys,${ }^{[11]}$ in this case, the special attention should be paid to when this alloy is added into steel. Furthermore, type $\mathrm{H}$ inclusions are lump-like $\mathrm{Al}-\mathrm{Si}-\mathrm{Ca}-\mathrm{Mg}-\mathrm{O}$ inclusions, which have melting points of about $1573 \mathrm{~K}$ to $1673 \mathrm{~K}\left(1300{ }^{\circ} \mathrm{C}\right.$ to $\left.1400{ }^{\circ} \mathrm{C}\right)$ according to the calculations using FactSage.

The number density of inclusions in the $\mathrm{HCFeCr}$ alloy is 96 inclusions $/ \mathrm{mm}^{2}$, which contains a large number of sulfides. The corresponding value in the $\mathrm{LCFeCr}$ alloys is 28 inclusions $/ \mathrm{mm}^{2}$. The $\mathrm{HCFeCr}$ alloys are usually added earlier in the steelmaking process, such as before the desulfurization or dephosphorization steps, while the $\mathrm{LCFeCr}$ alloys are usually added in the final refining stage to adjust the chemical composition of steel in the ladle refining process. From this point of view, the inclusions in the investigated $\mathrm{LCFeCr}$ alloys are more harmful to the steel cleanliness than those in the $\mathrm{HCFeCr}$ alloys since they have relatively higher melting points, larger size ranges, and less time to be removed from the liquid steel before casting.

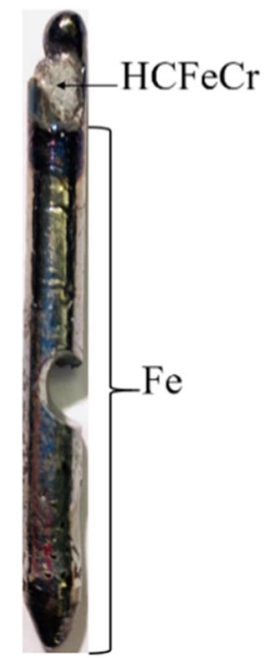

(a)

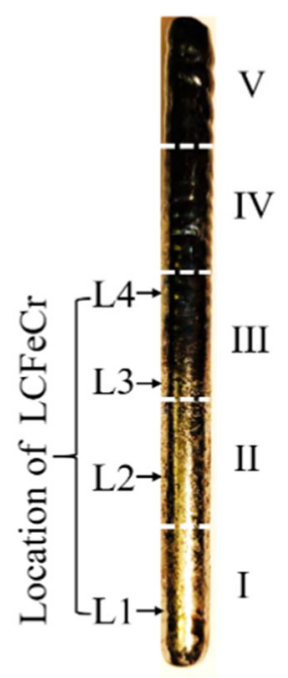

(b)
Fig. 3-Pictures of typical QT samples with locations of (a) $\mathrm{HCFeCr}$ and $(b) \mathrm{LCFeCr}$ pieces.

\section{B. Macroscopic Observations of the QT Samples}

According to the sampling by the proposed liquid-metal-suction method, it was found that the $\mathrm{HCFeCr}$ alloy pieces located only at the top of all QT samples, as shown in Figure 3(a). However, each QT sample with $\mathrm{LCFeCr}$ alloys was cut into five parts and investigated because the actual locations of the alloy pieces can be varied in the samples from the bottom part (as shown in Figure 3(b) for L1 sample) up to middle part.

The different locations of the $\mathrm{HCFeCr}$ and $\mathrm{LCFeCr}$ alloy pieces can be explained by the density differences. More specifically, according to the calculation by Thermo-Calc. $2020 \mathrm{a}^{[22]}$ with TFCE 10 database, ${ }^{[23]}$ the $\mathrm{LCFeCr}$ alloy has a density of $6850 \mathrm{~kg} \mathrm{~m}^{-3}$, which is quite close to that of the liquid $\mathrm{Fe}\left(6980 \mathrm{~kg} \mathrm{~m}^{-3}\right)$ at $1873 \mathrm{~K}\left(1600{ }^{\circ} \mathrm{C}\right)$, while the $\mathrm{HCFeCr}$ alloy has a smaller density of $5830 \mathrm{~kg} \mathrm{~m}^{-3}$ at $1873 \mathrm{~K}\left(1600{ }^{\circ} \mathrm{C}\right)$. It should be pointed out that the sizes of the remaining $\mathrm{HCFeCr}$ alloy pieces were not much changed during holding in the Fe melt. It means that they were not significantly melted or dissolved, which was similar to what was found for $\mathrm{FeNb}$ alloys. ${ }^{[9]}$ On the contrary, the $\mathrm{LCFeCr}$ alloy was melted since their sizes decreased significantly, which is discussed in detail later. According to the $\mathrm{Fe}-\mathrm{Cr}-\mathrm{C}$ phase diagram calculated using Factsage 7.2 with databases of FactPS and FSstel (Figure 4), the approximate melting point of the investigated $\mathrm{HCFeCr}$ alloy is above $1873 \mathrm{~K}\left(1600{ }^{\circ} \mathrm{C}\right)$, which indicates that the alloy piece cannot melt at the given experimental conditions. During the production of $\mathrm{HCFeCr}$ alloys through carbo-thermic reduction, $\mathrm{Cr}$ tends to react further with the available $\mathrm{C}$ to form $\mathrm{Cr}$ carbides $\left(\mathrm{Cr}_{7} \mathrm{C}_{3}\right.$ and/or $\mathrm{Cr}_{23} \mathrm{C}_{6}$ ). These carbides can also be seen from Figure 4, and they have complex crystalline structures. It was reported that the melting kinetics of $\mathrm{Cr}$ carbides was a very slow process, ${ }^{[24]}$ which could result in the slow dissolution of $\mathrm{HCFeCr}$ alloys. Another possible reason is that the $\mathrm{HCFeCr}$ alloy pieces were found on the top the samples, they were more possibly outside of the hot zone of the furnace, where the temperature was much lower compared to the melt.

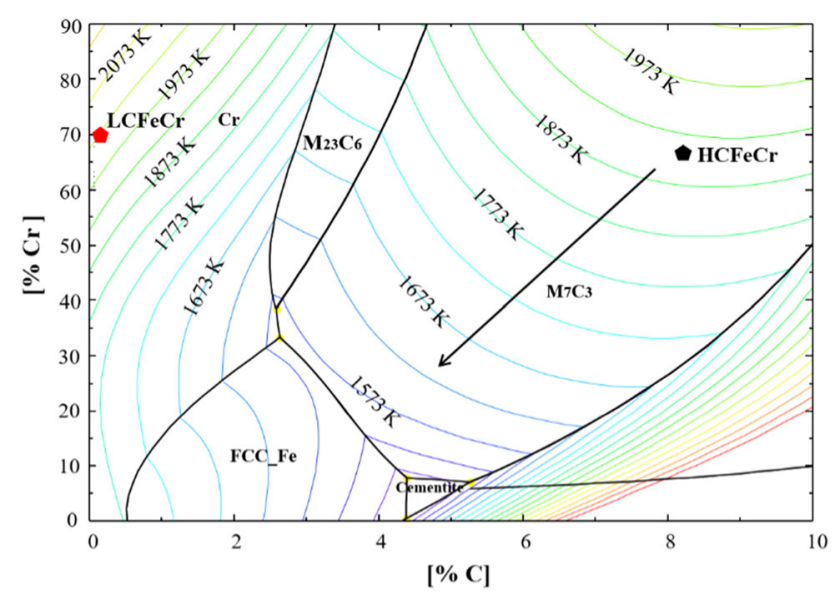

Fig. 4-Liquidus projection for the $\mathrm{Fe}-\mathrm{Cr}-\mathrm{C}$ ternary system. 


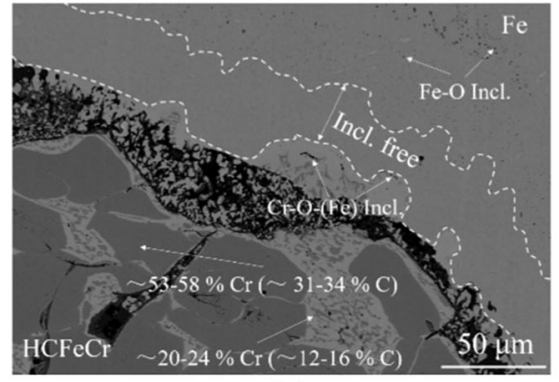

(a)

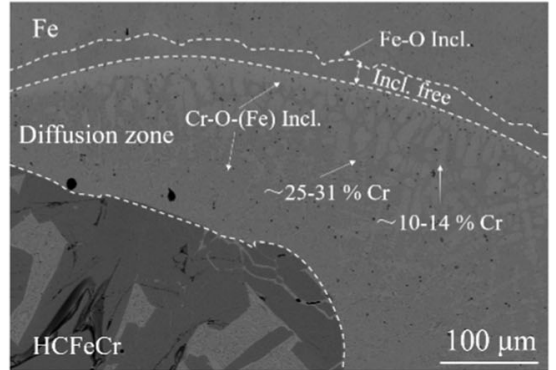

(b)

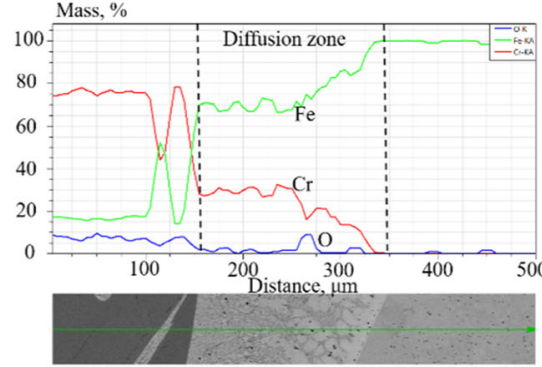

(c)

Fig. 5-The interfacial microstructures at the holding time of $(a) \mathrm{H} 1-5 \mathrm{~s},(b) \mathrm{H} 3-20 \mathrm{~s}$, and $(c)$ elemental line analysis of Fe and Cr contents in sample H3.

While in the case of $\mathrm{LCFeCr}$ alloy, its solidus temperature is about $1723 \mathrm{~K}\left(1450{ }^{\circ} \mathrm{C}\right)$ calculated using Factsage 7.2 with databases of FactPS and FSstel. Furthermore, the alloy pieces located inside the liquid melt zone, and they contacted with the liquid Fe. The physical contact led to a liquid/solid $\mathrm{Fe} / \mathrm{LCFeCr}$ interface which transferred the heat faster and accelerated the melting. In this case, even if the theoretical liquidus temperature of $\mathrm{LCFeCr}$ is more than $1973 \mathrm{~K}\left(1700{ }^{\circ} \mathrm{C}\right)$, the alloy pieces were significantly melted during holding in the Fe melt at $1873 \mathrm{~K}\left(1600^{\circ} \mathrm{C}\right)$. The early dissolution and melting behaviors and the inclusion formations between the liquid $\mathrm{Fe}$ and the two alloys are discussed in the following sections.

\section{C. $\mathrm{Fe}-\mathrm{HCFe} \mathrm{Cr}$ Interactions}

It was found that the $\mathrm{HCFeCr}$ alloy slowly dissolved during the short holding time ( 5 to 30 seconds) in the $\mathrm{Fe}$ melt. Interdiffusion of $\mathrm{Fe}$ and $\mathrm{Cr}$ resulted in the formation of a diffusion zone, bounded by two diffusion fronts. Diffusion fronts 1 and 2 are located at the diffusion zone/bulk $\mathrm{Fe}$ and diffusion zone $/ \mathrm{FeCr}$ interface, respectively. Figure 5 shows the microstructures of sample H1, H3, and the elemental line analysis of the diffusion zones in sample $\mathrm{H} 3$. When the holding time is 5 seconds (Figure 5(a)), the diffusion zone cannot be clearly distinguished. It can be seen that there are two main phases inside the $\mathrm{HCFeCr}$ alloy, i.e., a light grey phase consisting of 20 to 24 mass pet $\mathrm{Cr}$ and 12 to 16 mass pet $\mathrm{C}$ and a dark grey phase consisting of 53 to 58 mass pct $\mathrm{Cr}$ and 31 to 34 mass pet $\mathrm{C}$. It should be noticed that the contents of $\mathrm{C}$ are qualitatively determined by EDS, sometimes they can be overestimated. However, they can show the presence of carbides, which is in a good agreement with the thermodynamic calculation result (Figure 4). With an increased holding time, an obvious diffusion layer appears and grows. As shown in sample $\mathrm{H} 3$ (Figure 5(b)), the diffusion zone composes of two $\mathrm{Fe}-\mathrm{Cr}$ phases, i.e., a grey one containing 25 to 31 mass pet $\mathrm{Cr}$ and another light one containing 10 to 14 mass pet $\mathrm{Cr}$. Due to the interdiffusions of $\mathrm{Fe}$ and $\mathrm{Cr}$, continuous gradients of $\mathrm{Fe}$ and $\mathrm{Cr}$ contents are formed in the diffusion zone. These different phases might be formed by element segregation at a decreased temperature during the solidification process.

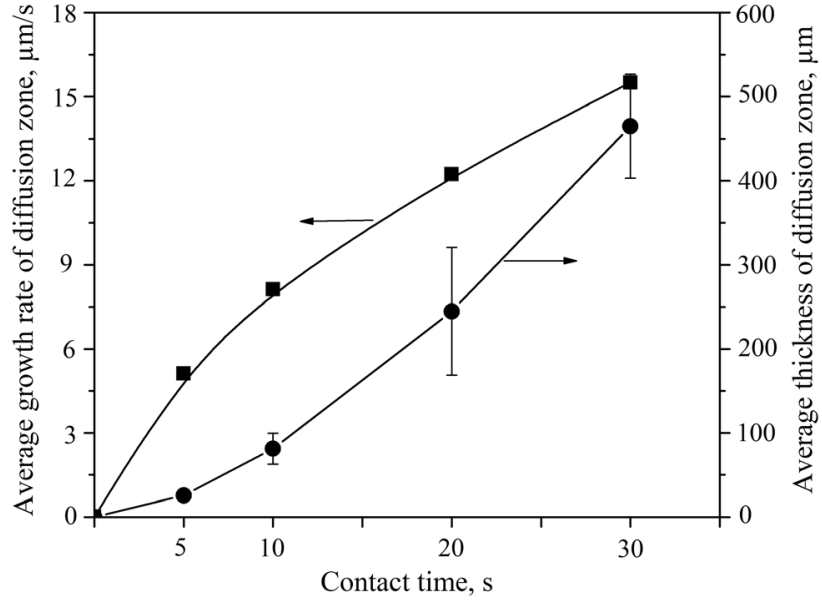

Fig. 6-The average thickness and growth rate of the diffusion zone versus holding time.

The line scan analysis shows that the $\mathrm{Cr}$ content significantly decreases from the diffusion front 2 and thereafter slightly decreases with some fluctuations due to the existence of different $\mathrm{Fe}-\mathrm{Cr}$ phases (Figure 5(c)). The average thickness and the growth rate of the diffusion zone versus the holding time are plotted in Figure 6. As can be seen, the thickness of the diffusion zone increases with an increased holding time. More specifically, this zone is around $25 \pm 5 \mu \mathrm{m}$ after 5 seconds, alternatively, it reaches about $460 \pm 60 \mu \mathrm{m}$ after 30 seconds. The relationship between the growth rate of diffusion zone and the holding time looks parabolic with its axis of symmetry lying on the $x$-axis indicating that decreased growth of the diffusion zone with time. This might be due to the increasing diffusion zone thickness which itself acts as a diffusion barrier.

Figure 7 shows the inclusions in the enlarged diffusion zones and the bulk Fe areas. As can be seen in Figure 7(a), an "inclusion-free" zone was distinguished between the bulk $\mathrm{Fe}$ and the diffusion zone. In the diffusion zone, the majority of inclusions were found to be Cr-O-(Fe) (Figure 7(b)), and the Fe contents in these inclusions varied from 5 mass pet to 42 mass pet. However, by the EDS determination of compositions of inclusions on the polished surface of the metal sample (2D method), the metal matrix can significantly 


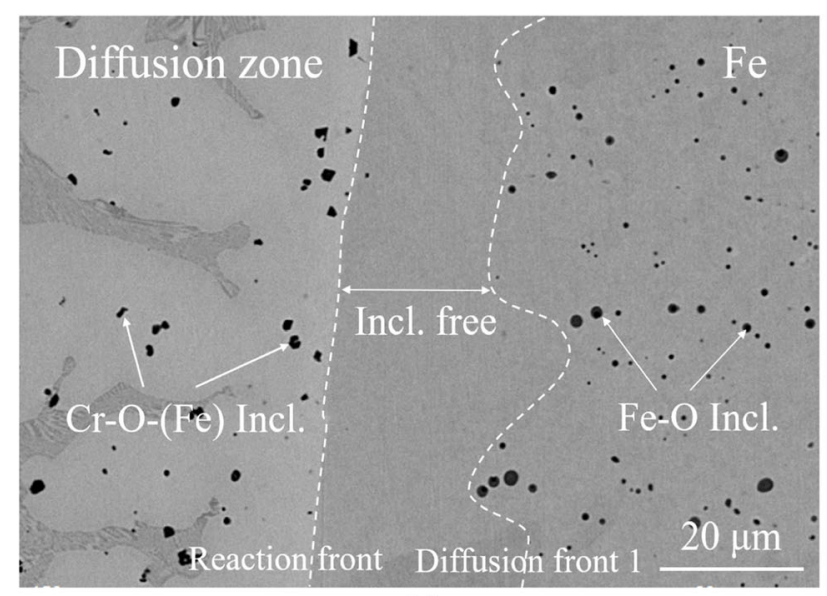

(a)

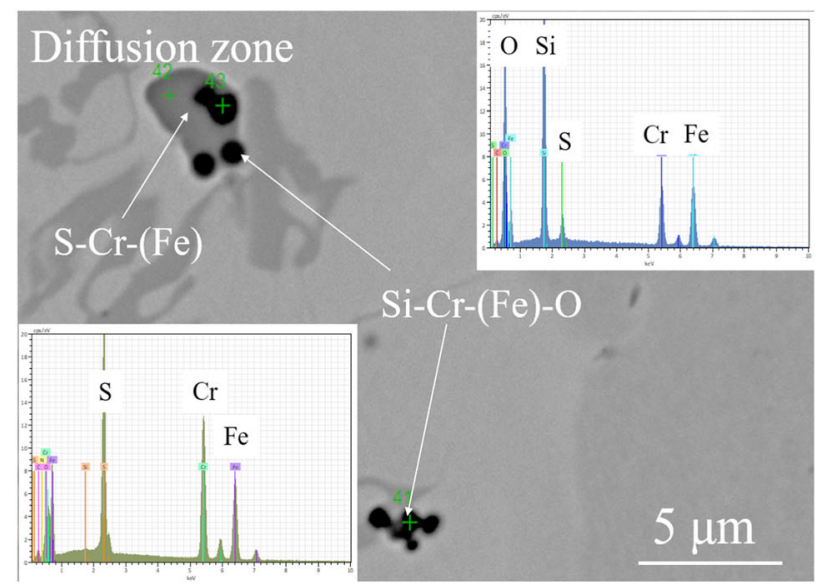

(c)

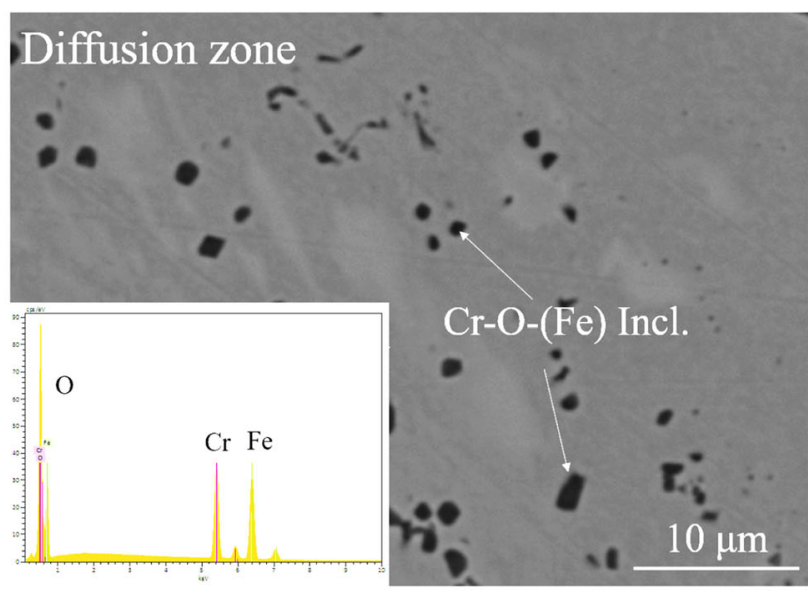

(b)

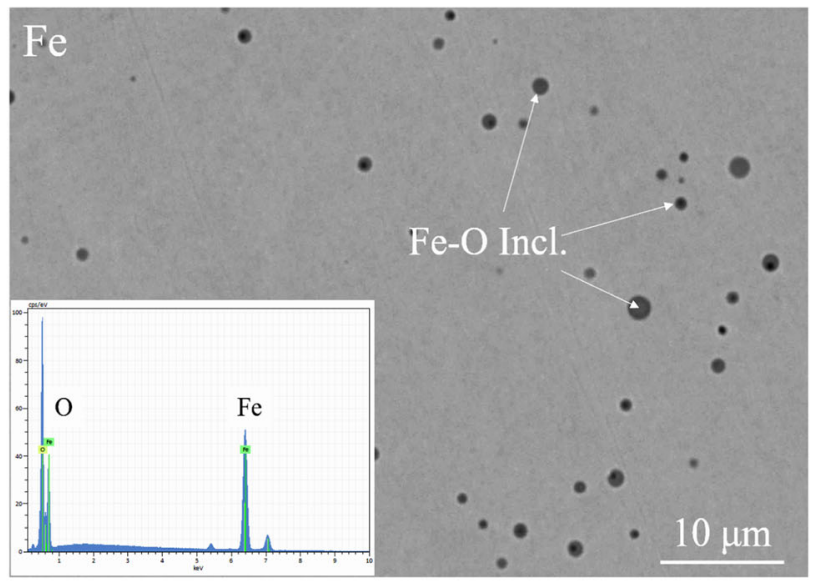

(d)

Fig. 7-(a) Overview of the different zones, $(b),(c)$ inclusions in the enlarged diffusion zones, and (d) $\mathrm{FeO}$ inclusions in the bulk Fe.

misrepresent of the obtained results (especially small size inclusions). ${ }^{[25]}$ Therefore, the real ratio of main components (such as $\mathrm{Cr}$ and $\mathrm{Fe}$ ) in the investigated oxides can significantly differ from the obtained results. In addition, $\mathrm{Si}$ - and $\mathrm{S}$-contained inclusions were also found (as shown in Figure 7 (c). It can be speculated that the $\mathrm{SiO}_{2}$ might originate from the quartz tube. And the $(\mathrm{Cr}, \mathrm{Fe}) \mathrm{S}$ inclusions might be from the $\mathrm{HCFeCr}$ alloy, which corroborated that this area was most likely liquid as the inclusions could move. Moreover, the high $\mathrm{O}$ content in liquid $\mathrm{Fe}$ resulting in $\mathrm{FeO}$ inclusions in the bulk $\mathrm{Fe}$ (Figure 7(d)).

To get more clear information of the inclusions in different areas, a short time electrolytic etching was applied. The inclusion characteristics in different areas on the metal surface after etching are illustrated in Table IV. It can be seen that the inclusions in the diffusion zone were pure $\mathrm{Cr}_{2} \mathrm{O}_{3}$ inclusions with a very small amount of $\mathrm{FeO}$ and $\mathrm{SiO}_{2}$ contents. It should be noted that the effect of the matrix on the inclusion composition was much smaller compared to the 2D method, which was verified in a previous paper. ${ }^{[26]}$ In terms of the inclusions at the boundary between the diffusion zone and the "inclusion-free" zone, they had higher $\mathrm{FeO}$ content $(\sim 20$ mass pct). This closely related to the interdiffusion of $\mathrm{Fe}$ in the diffusion zone where the $\mathrm{Fe}$ contents was higher at the diffusion zone/bulk $\mathrm{Fe}$ interface. In the "inclusion-free" zone, very small $\mathrm{FeO}$ $(<1 \mu \mathrm{m})$ inclusions with less than 2 mass pct $\mathrm{Cr}_{2} \mathrm{O}_{3}$ were found. The presence of a small fraction of $\mathrm{Cr}_{2} \mathrm{O}_{3}$ was due to the fact that the larger diffusivity of $\mathrm{Cr}$ in liquid $\mathrm{Fe}$ than that in solidified Fe. Moreover, these too small inclusions can hardly be observed on the polished surface. In bulk $\mathrm{Fe}$ zone, almost pure $\mathrm{FeO}$ inclusions having size about 0.3 to $4 \mu \mathrm{m}$ were observed.

Previous studies ${ }^{[4,7,27-29]}$ have reported that the number of the formed inclusions increased with an increasing initial $\mathrm{O}$ content in the liquid $\mathrm{Fe}$. However, the average inclusion size tended to decrease. In addition, the initial $\mathrm{O}$ content also influenced the growth and morphology of the inclusions. The inclusion shape evolution from a faceted morphology prevailing at low initial $\mathrm{O}$ contents to a spherical morphology appearing at higher initial $\mathrm{O}$ contents can be explained by higher supersaturation conditions. Moreover, the higher $\mathrm{O}$ content was reported to locally raise the temperature at the reaction front by releasing chemical heat of deoxidation, which consequently enhanced the internal dissolution. The formation of $\mathrm{Fe}-\mathrm{Cr}-\mathrm{O}$ and $\mathrm{FeOx}$ inclusions under different $\mathrm{O}$ contents were calculated by using Factsage 
Table IV. Inclusion Characteristics in Different Zones on the Metal Surface of H3 Sample After Short Electrolytic Etching

Location
Photo

7.2 with the database of FToxid and FSstel, as shown in Figure 8. It can be seen that the only $\mathrm{FeCr}_{2} \mathrm{O}_{4}$ spinel inclusions can be formed at the $\mathrm{Cr}$ content is about 1 mass pet (Figure 8(a)). Moreover, the amount of $\mathrm{FeCr}_{2} \mathrm{O}_{4}$ inclusions increase with the increase of $\mathrm{O}$ content. The inclusions found at the boundary between the diffusion and inclusion-free zones can be explained from this point. It should be noticed that the formation temperature of $\mathrm{FeCr}_{2} \mathrm{O}_{4}$ inclusions increases with the increase of $\mathrm{O}$ content, indicating that the $\mathrm{FeCr}_{2} \mathrm{O}_{4}$ inclusions are more easily formed for higher $\mathrm{O}$ contents. With the increase of $\mathrm{Cr}$ content to 10 mass pct (corresponds to the lowest $\mathrm{Cr}$ concentrations in the grey $\mathrm{Fe}-\mathrm{Cr}$ phases in the diffusion zone), $\mathrm{Cr}_{2} \mathrm{O}_{3}$ inclusions are more easily formed instead of $\mathrm{FeCr}_{2} \mathrm{O}_{4}$ inclusions at lower $\mathrm{O}$ contents (Figure 8(b)). When the $\mathrm{O}$ content is 1000 ppm, $\mathrm{FeCr}_{2} \mathrm{O}_{4}$ inclusions first form and then change to $\mathrm{Cr}_{2} \mathrm{O}_{3}$ with decreasing temperature. However, only $\mathrm{Cr}_{2} \mathrm{O}_{3}$ inclusions can form for 25 mass pet $\mathrm{Cr}$ (corresponds to the lowest $\mathrm{Cr}$ concentrations in the light $\mathrm{Fe}-\mathrm{Cr}$ phases in the diffusion zone). Therefore, it can be concluded that $\mathrm{Cr}_{2} \mathrm{O}_{3}$ inclusions are the stable phases for higher $\mathrm{Cr}$ contents. Under the current experimental conditions, $\mathrm{Cr}_{2} \mathrm{O}_{3}$ inclusions were formed rather than $\mathrm{FeCr}_{2} \mathrm{O}_{4}$ inclusions in the diffusion zones. In addition, the high $\mathrm{O}$ content in liquid $\mathrm{Fe}$ resulting in $\mathrm{FeO}$ inclusions in the bulk Fe. According to the calculation results (Figure 8(c)), the amount of $\mathrm{FeO}_{x}$ inclusions increases with the increase of $\mathrm{O}$ content. With the decrease of temperature, liquid $\mathrm{Fe}$ starts to solidify and liquid inclusions $\left(\mathrm{FeO}-\mathrm{Fe}_{2} \mathrm{O}_{3}\right)$ are formed and then transformed to $\mathrm{FeO}$ inclusions at about $1650 \mathrm{~K}$ $\left(1377^{\circ} \mathrm{C}\right)$. Therefore, no inclusions can form in the liquid $\mathrm{Fe}$ melt and $\mathrm{FeO}$ inclusions are formed during the solidification of QT samples.

To achieve a better understanding of the early dissolution process of $\mathrm{HCFeCr}$ alloy, the metal surface after short electrolytic etching and the schematic illustration is proposed in Figure 9. A dendritic morphology can be observed in the diffusion zone. It can be explained by a constitutional undercooling during quenching of the QT samples due to the existence of temperature gradient between the $\mathrm{HCFeCr}$ alloy and diffusion zone. In the moment of immerging of alloy into the Fe melt, a solid Fe shell is formed around the alloy piece due to fast freezing of liquid Fe melt. This shell is called the "inclusion-free" zone. Actually, FeO inclusions can form in this zone upon solidification (Table IV). However, their sizes are much smaller compared to those in the bulk Fe areas since they do not have time to grow during the freezing process. The thickness of the observed "inclusion-free" zone slightly decreased with the holding time, it was around 30 to $40 \mu \mathrm{m}$ for 5 seconds and 21 to $25 \mu \mathrm{m}$ for 30 seconds. This is due to the heating and melting of the freezed Fe layer on the surface of the alloy piece.

These findings are different from the previous works, ${ }^{[4,7]}$ where they reported that the "inclusion-free" zone was formed due to the lower $\mathrm{O}$ contents in this zone compared to the bulk $\mathrm{Fe}$ at high temperature, which was caused by the consumptions of alloying elements and Fe. However, there was no obvious difference of $\mathrm{O}$ concentration between these two areas in this study. Therefore, it is more likely that the "inclusion-free" zone was formed by fast freezing of the Fe. Moreover, the "inclusion-free" zone acts as a temperature boundary between the liquid Fe and alloy piece, and heat of liquid $\mathrm{Fe}$ is continually transferred to the surface of the alloy through this boundary layer. As was mentioned before, the $\mathrm{HCFeCr}$ alloy can only be dissolved under the current condition. However, the melting temperature of the surface layer of $\mathrm{HCFeCr}$ alloy decreased significantly due to the interdiffusions of $\mathrm{Cr}, \mathrm{C}$, and $\mathrm{Fe}$, as can be seen by the arrow direction in Figure 4. At a certain time, the melting point of the surface layer became lower compared to that of the freezing Fe shell, as shown in Figure 9(b). As a result, a 


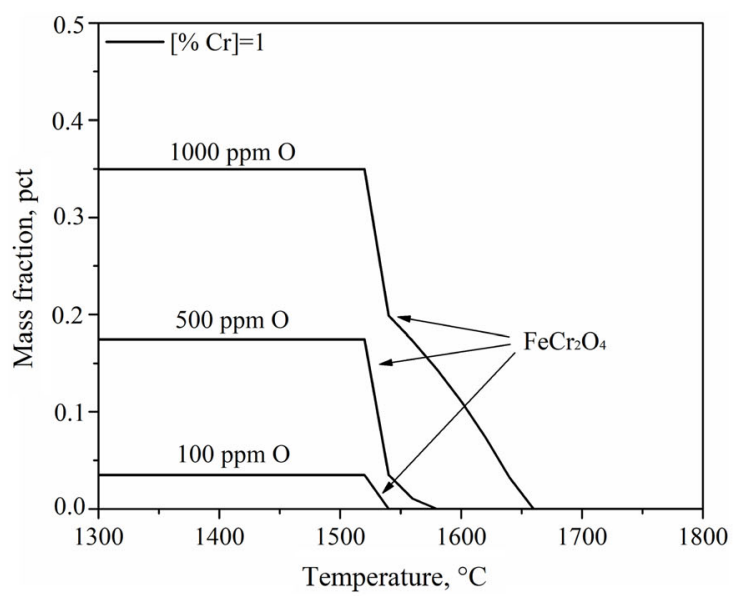

(a)

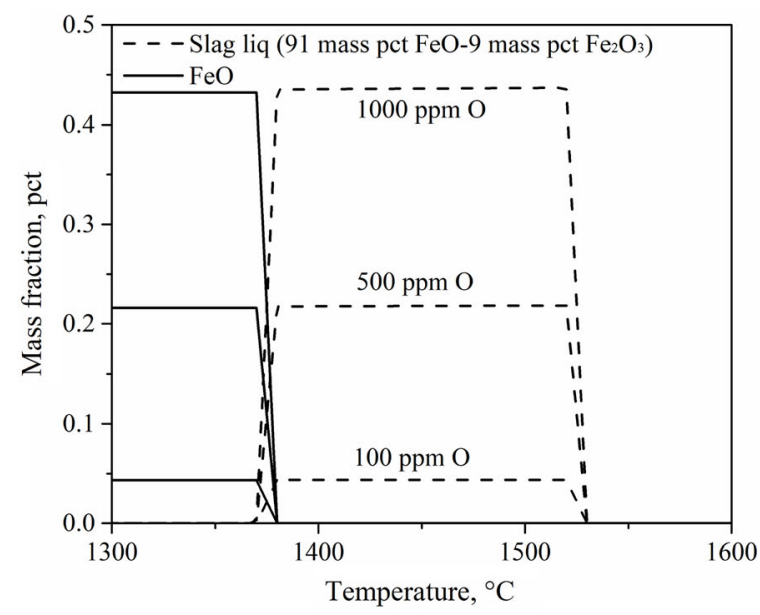

(c)

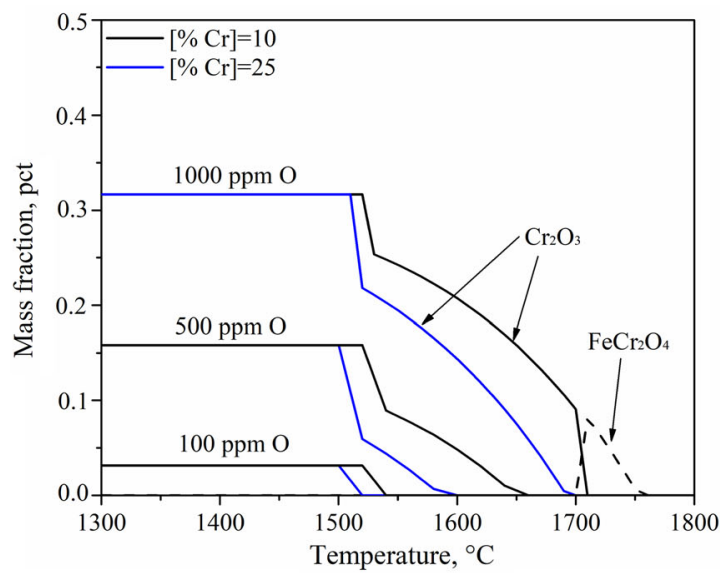

(b)

Fig. 8-The predictions of $(a),(b) \mathrm{Fe}-\mathrm{Cr}-\mathrm{O}$, and (c) $\mathrm{FeO}_{\mathrm{x}}$ inclusions formations.

liquid diffusion zone formed between the alloy and the "inclusion-free" zone. At the same time, the formation and growth of $\mathrm{Cr}_{2} \mathrm{O}_{3}$ and $\mathrm{Cr}_{2} \mathrm{O}_{3}-\mathrm{FeO}$ were depending on the local $\mathrm{Cr}$ and $\mathrm{Fe}$ contents at different locations in the diffusion zone. The $\mathrm{FeO}$ inclusions were not present in the Fe melt and can only form during the solidification of QT samples.

\section{D. $\mathrm{Fe}-\mathrm{LCFeCr}$ Interactions}

After bringing the $\mathrm{LCFeCr}$ alloy into contact with liquid $\mathrm{Fe}$ for the determined time, the morphology of the alloy piece changed obviously, which suggested that the alloy was melted during this short time. Figure 10 shows the backscattered electron (BSE) images of the alloy in sample L1-5 seconds and L3-20 seconds and the size change as well as the location of the alloy piece in quenched QT samples versus the holding time. It should be pointed out that the original $\mathrm{LCFeCr}$ alloy pieces have almost the same sizes $(4 \mathrm{~mm})$. In sample L1, the melting of the alloy cannot be clearly distinguished as their size is close to the original size. However, with increasing the holding time, the alloy starts to melt and dissolve. The unmelted part is shown in Figure 10(b).
The size of the alloy piece sharply decreases from 5 to 10 seconds (Figure 10(c)), indicating that the start of melting time for the $\mathrm{LCFeCr}$ piece $(4 \mathrm{~mm})$ is between 5 to 10 seconds. The size change rate becomes much slower after 10 seconds, which suggests that the melting and dissolution of $\mathrm{LCFeCr}$ alloy are much faster at the beginning ( 5 to 10 seconds) of the contact. One interesting point should be noticed that the location of the unmelted alloy also changes with time. The alloy piece locates at about $6 \mathrm{~mm}$ from the bottom of the solidified sample with the contact time of 5 seconds. Then, it moves up and locates at about $58 \mathrm{~mm}$ from the bottom of the sample for 30 seconds contact time, which is schematically shown in Figure 3(b). This can be attributed to the fact that the density of $\mathrm{LCFeCr}$ alloy $\left(6850 \mathrm{~kg} \mathrm{~m}^{-3}\right)$ is still slightly smaller than that of pure Fe $\left(6980 \mathrm{~kg} \mathrm{~m}^{-3}\right)$.

Although the $\mathrm{LCFeCr}$ alloy melted to some extent, a diffusion zone was also formed. Figure 11 shows the microstructure of the diffusion zone as a function of the holding time. Two phases were found inside the $\mathrm{LCFeCr}$ alloy, a light one consisting of 65 to 70 mass pet $\mathrm{Cr}$ and a grey one consisting of 80 to 84 mass pct $\mathrm{Cr}$ (Figure 11(a)). Similarly, two regions were observed in the 


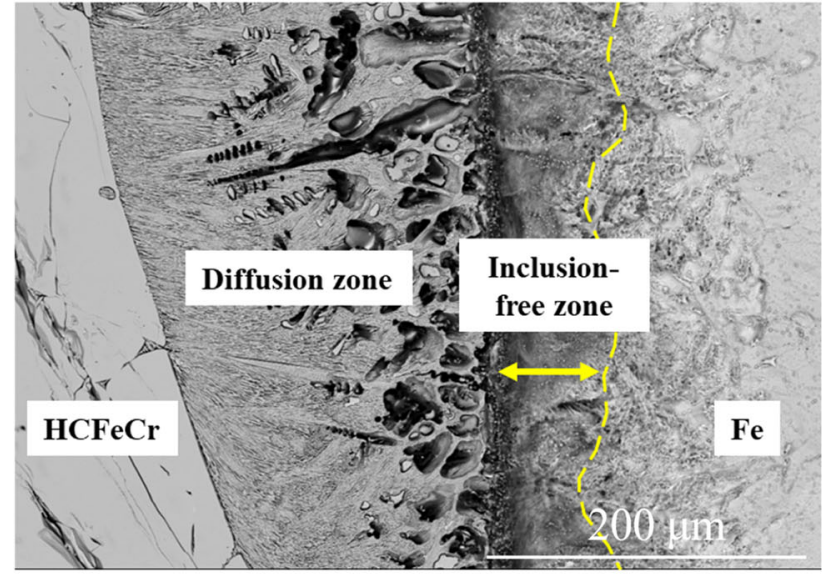

(a)

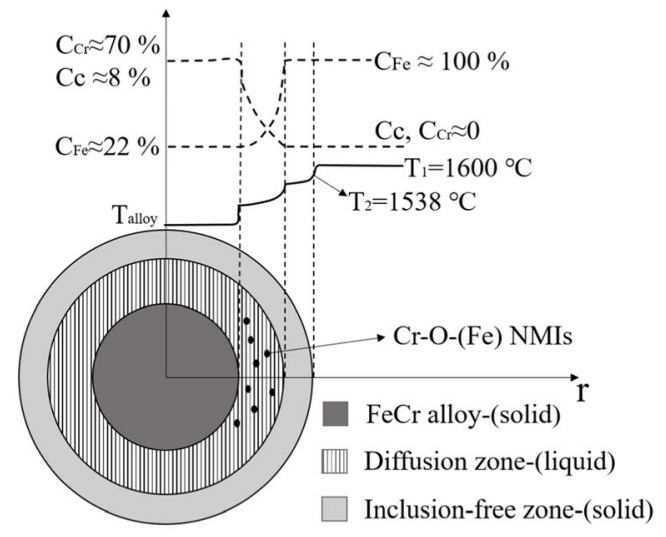

(b)

Fig. 9- (a) SEM image of different zones of H3 sample after short electrolytic etching and (b) schematic diagram of temperature and concentration profiles for dissolution process.

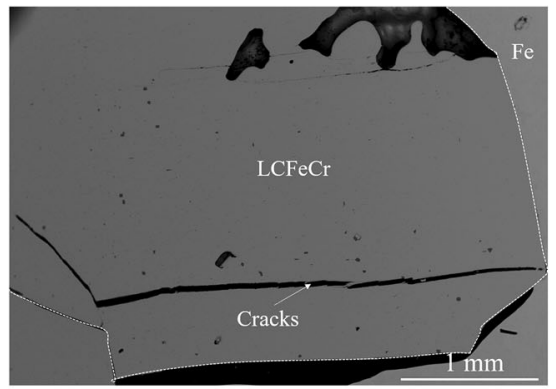

(a) $\mathrm{L} 1-5 \mathrm{~s}$

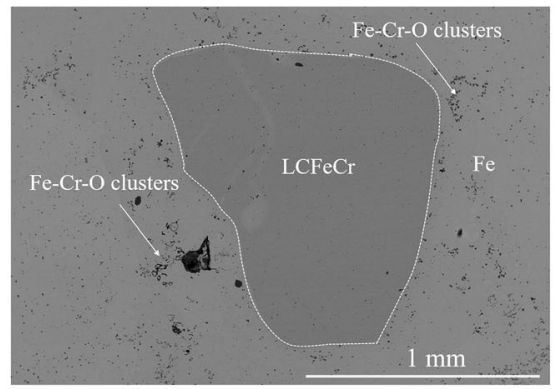

(b) $\mathrm{L} 3-20 \mathrm{~s}$

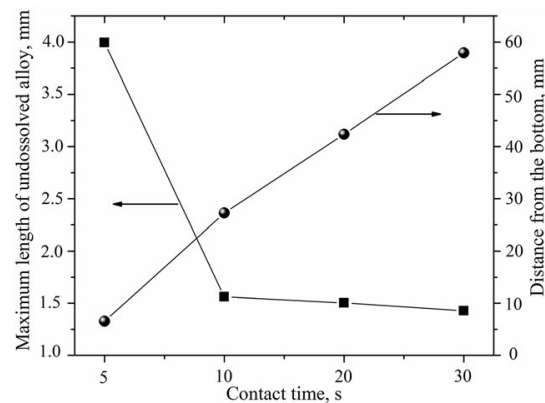

(c)

Fig. 10 - The morphology of unmelted alloy $(a) \mathrm{L} 1,(b) \mathrm{L} 3$, and $(c)$ location and size of the unmelted alloy.

Fe-rich side, i.e., one containing numerous $\mathrm{FeO}$ inclusions and another "inclusion-free" zone (thickness $31 \mu \mathrm{m}$ on average), which has been discussed before. With the increase of holding time, the solid Fe shell started to melt due to the continuous heat supply from the liquid $\mathrm{Fe}$, and finally this "inclusion-free" zone was disappeared. (Figure 11(b)). Meanwhile, a large number of Fe-Cr-O inclusions were formed and observed in the diffusion zone (Figures 11(b) through (d)). Furthermore, these inclusions existed not limited to the diffusion zone, they were also found in the bulk Fe in the L4-30 seconds sample (Figure 11(d)). The formation of Fe-Cr-O inclusions in the melt consumed some amount of $\mathrm{O}$ from the bulk $\mathrm{Fe}$. As a result, less number and small size $\mathrm{FeO}$ inclusions can be formed during the solidification. In addition, a smooth $\mathrm{Fe}$ /diffusion zone interface suggesting the presence of a liquid diffusion zone at the experimental temperature. In addition to the diffusion of $\mathrm{Cr}$ to the liquid $\mathrm{Fe}$, the partially melted $\mathrm{FeCr}$ alloy resulted in dissolved $\mathrm{Cr}$ in the liquid zone. They reacted with $\mathrm{Fe}$ and $\mathrm{O}$ in the iron melt to form $\mathrm{Fe}-\mathrm{Cr}-\mathrm{O}$ inclusions.

Figure 12 shows the measured $\mathrm{Cr}$ and $\mathrm{Fe}$ concentrations for various samples as a function of the distance from the diffusion front 2 . Since the concentration changes of $\mathrm{Fe}$ and $\mathrm{Cr}$ are exactly opposite, here only the $\mathrm{Cr}$ concentration profile is discussed. $\mathrm{The} \mathrm{Cr}$ content in sample L1 sharply decreases from $\sim 70$ mass pet to almost 0 in a distance of about $30 \mu \mathrm{m}$. In other samples, the $\mathrm{Cr}$ concentration decreases drastically on a boundary between the $\mathrm{LCFeCr}$ alloy and diffusion zone. Then, the concentration of $\mathrm{Cr}$ in the liquid diffusion zone decreases slowly because a distribution of dissolved $\mathrm{Cr}$ in the liquid phase can be done relatively faster. These two contents correspond to the ranges of $\alpha-\mathrm{FeCr}$ and $\gamma$ $\mathrm{Fe}(\mathrm{Cr})$ phases based on the $\mathrm{Fe}-\mathrm{Cr}$ phase diagram. ${ }^{[14]}$ One possible reason might be related to their different interdiffusion coefficients in these two phases. The similar phenomenon has been confirmed during the dissolution of $\mathrm{Mn}$ in liquid $\mathrm{Fe}^{[4]}$

The total diffusion distance marked with the $\mathrm{Cr}$ content from the diffusion front 2 corresponds to the thickness of the diffusion zone. As shown in Figure 12(a), the thickness of the diffusion zone is significantly larger after the holding for 10 seconds $(\sim 420 \mu \mathrm{m})$ compared to 5 seconds $(\sim 30 \mu \mathrm{m})$. The latter indicates that only limited interdiffusion has occurred at the early stages of the contact, which might be attributed to the limited time. Another reason is the formation of a solid Fe shell, i.e., the liquid Fe solidifies when contacting the cold alloy piece, where the shell inhibits the $\mathrm{Cr}$ diffusion. However, this Fe shell melts when the holding 


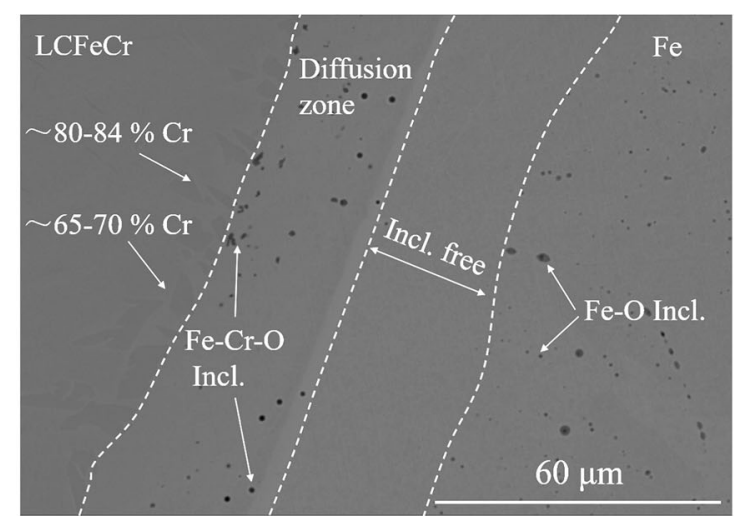

(a)

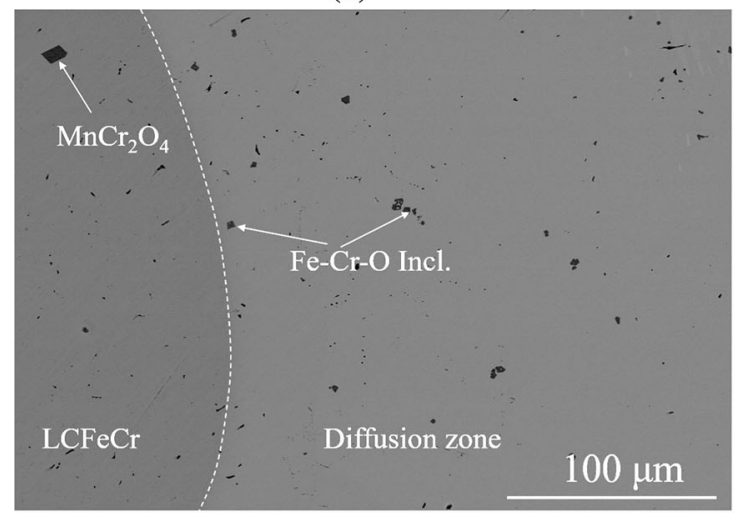

(c)

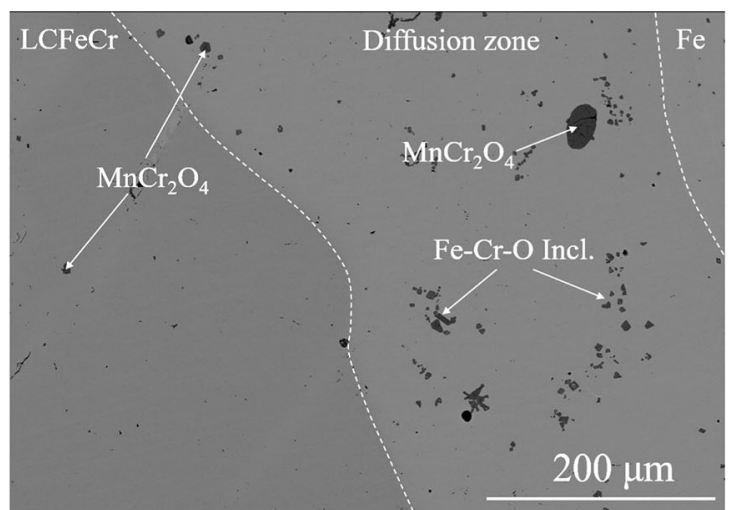

(b)

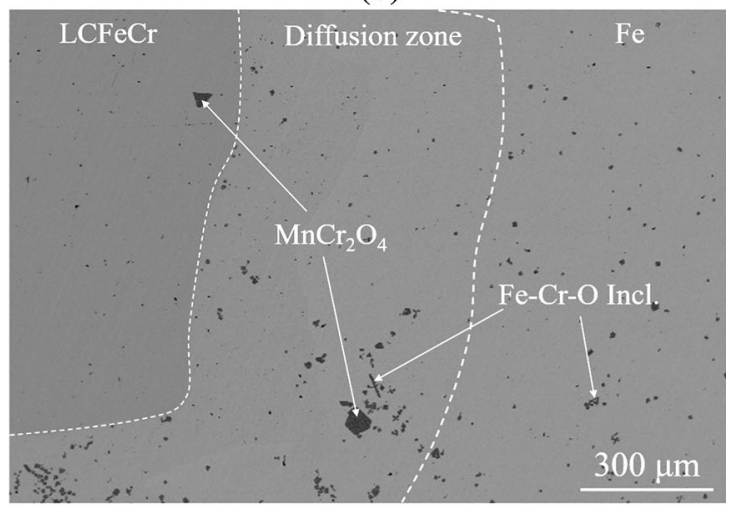

(d)

Fig. 11-The interfacial microstructure with different holding time (a) L1-5 s, (b) L2-10 s, (c) L3-20 s, and (d) L4-30 s.

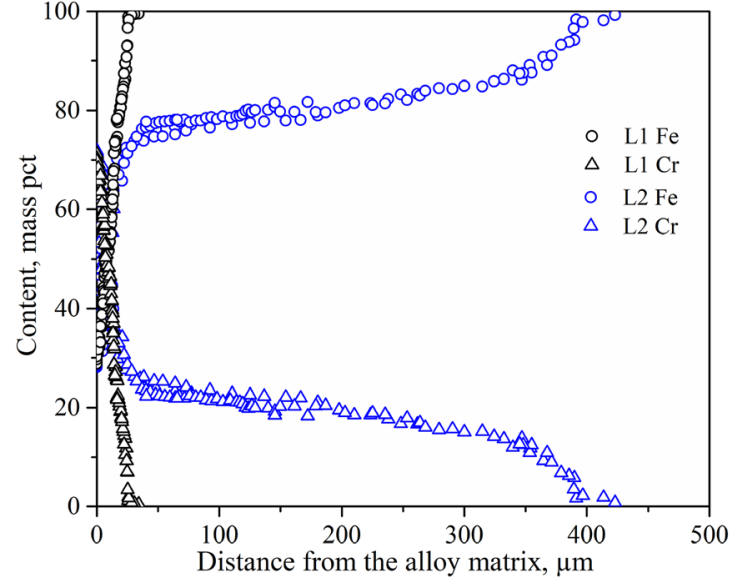

(a)

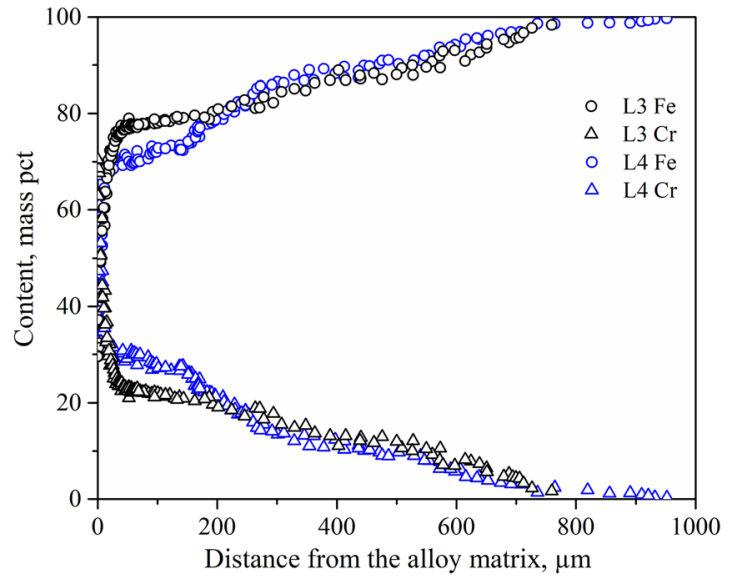

(b)

Fig. 12-Measured $\mathrm{Cr}$ and Fe concentration profiles in (a) L1 and L2 and (b) L3 and L4 samples.

time increases to 10 seconds, yielding a faster diffusion. In addition, the $\mathrm{Cr}$ profile extends over a larger distance due to the longer diffusion time in samples L3-20 seconds and L4-30 seconds.

Except for the interdiffusion between $\mathrm{Fe}$ and $\mathrm{FeCr}$ alloy, the inclusion behavior is also an interesting point. The newly formed Fe-Cr-O inclusions are the dominant type during the experiments. As was discussed before that the $\mathrm{LCFeCr}$ alloy partially melt upon the contact for 10 seconds and resulted in a large amount of
$\mathrm{Fe}-\mathrm{Cr}-\mathrm{O}$ inclusions. Plenty of these inclusions were found in all parts of samples L2, L3, and L4. Figure 13 shows the distributions of these inclusions under the same magnification in the parts of I, III, and V in sample L3 (Figure 3(b)). It can clearly be seen that the inclusions are larger in size and fewer in number in the bottom part I. However, an opposite tendency for the inclusion characteristics is found in the upper part $\mathrm{V}$. The detailed inclusion characteristics (average size, $N_{\mathrm{A}}$, area fraction) are presented in Figure 14. 


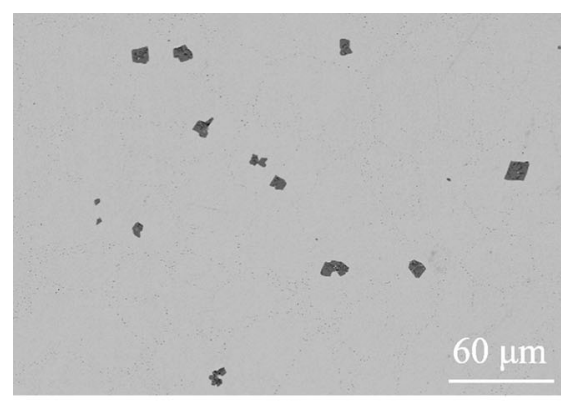

(a)

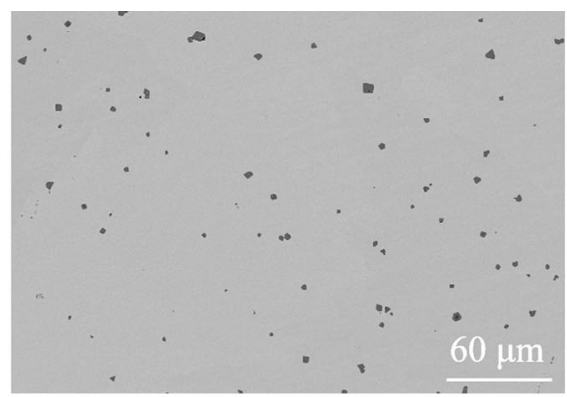

(b)

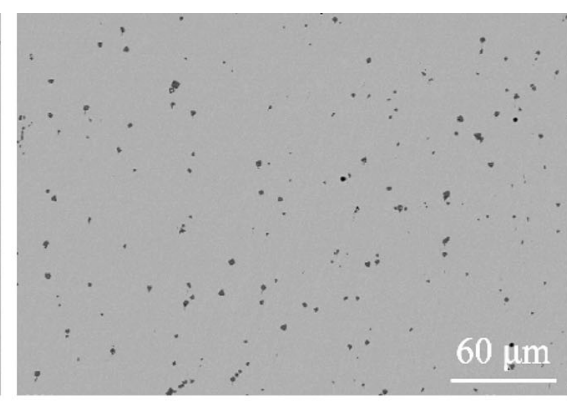

(c)

Fig. 13-Distribution of Fe-Cr-O inclusions in different parts of sample L3 (a) I, (b) III, and (c) V.

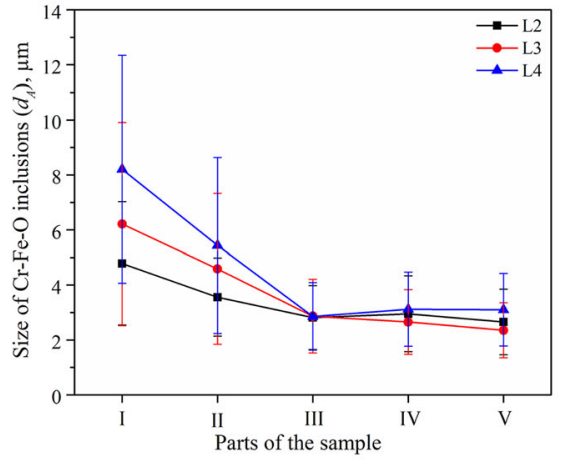

(a)

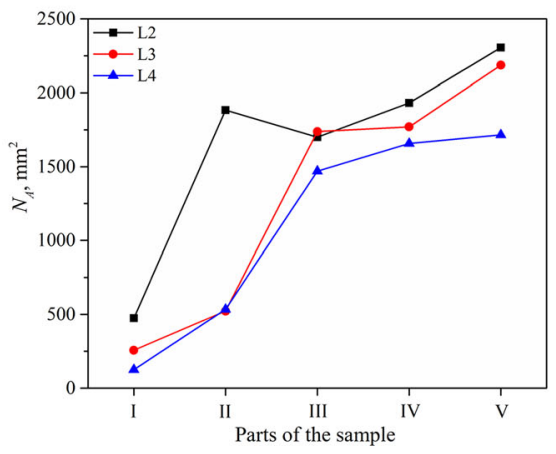

(b)

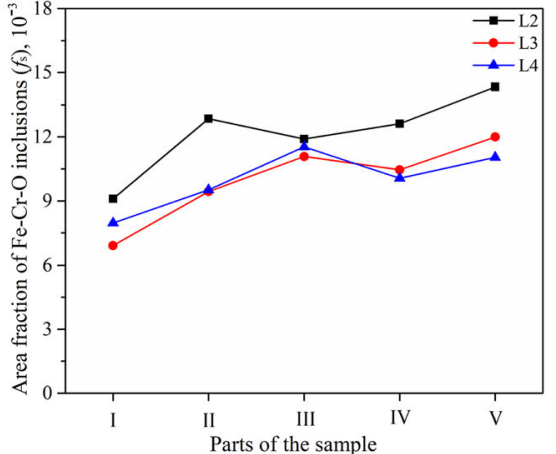

(c)

Fig. 14 -The characteristics of Fe-Cr-O inclusions in different parts of samples $(a)$ size, $(b) N_{\mathrm{A}}$, and (b) area fraction.

The average sizes of inclusions obviously decrease from part I to part III and then keep stable or slightly decrease from part III to part $\mathrm{V}$ for all the three samples (Figure 14(a)). Regarding the number of inclusions per unit area $\left(N_{\mathrm{A}}\right)$, it rapidly increases from part I to part III, after which it slowly increases for sample L3 and L4. While in sample L2, it reaches a peak in part II and then slowly increases after a slight decrease. The quick increase or the presence of the peak might be related to the location of the unmelted alloy, where more inclusions were formed closer to the alloy due to the higher $\mathrm{Cr}$ contents in this area. The area fraction of inclusions can be equivalent to the result of comprehensive consideration of the number and size of inclusions. It illustrates an increasing tendency from the bottom to the top of the sample, which is similar to that of $N_{\mathrm{A}}$ (Figure 14(c)). Moreover, it shows a more obvious peak for all the three samples where the unmelted alloys are located.

These characteristics can be explained simply as follows: after the alloy which originally located in the bottom contacted with the molten Fe, it started to melt and resulted in a large amount of dissolved $\mathrm{Cr}$. Meanwhile, a lot of $\mathrm{Fe}-\mathrm{Cr}-\mathrm{O}$ inclusions were formed in the melt. With an increased holding time, the alloy slowly moved upwards and the melted part became larger, which resulted in more dissolved $\mathrm{Cr}$ contents and $\mathrm{Fe}-\mathrm{Cr}-\mathrm{O}$ inclusions. Besides, the inclusions formed earlier at the bottom part had a longer time to grow, therefore they had larger sizes than those in the upper part. To sum up, the characteristics (number, size, distribution) of $\mathrm{Fe}-\mathrm{Cr}-\mathrm{O}$ inclusions are closely related to the dissolution and melting behavior of the $\mathrm{LCFeCr}$ alloy: (i) Before the alloy melted, Fe-Cr-O inclusions were formed only in the diffusion zone due to the interdiffusion of $\mathrm{Cr}$ and $\mathrm{Fe}$; (ii) Once the alloy started to melt, they were formed in the whole sample due to the dissolved $\mathrm{Cr}(\sim 0.5$ mass pet $)$ in the melt.

In addition, the compositions of $\mathrm{Fe}-\mathrm{Cr}-\mathrm{O}$ inclusions larger than $4 \mu \mathrm{m}$ were measured, which decreased the effect of the matrix on the inclusion composition. The results showed that they contained around 58 to 65 mass pet $\mathrm{Cr}_{2} \mathrm{O}_{3}$ and 35 to 42 mass pct $\mathrm{FeO}$. Moreover, the average atomic ratio of $\mathrm{Cr} / \mathrm{Fe}$ is around 2, which indicates that $\mathrm{FeCr}_{2} \mathrm{O}_{4}$ is a stable product at the present condition. Figure 15 shows the typical morphologies of $\mathrm{FeCr}_{2} \mathrm{O}_{4}$ inclusions. Irregular inclusions were dominant (Figures 15(a) and (b)), often observed as individual particles. Agglomerated inclusions were found as well, which can form clusters due to their floatation and agglomeration in the melt. Experimental evidence of this phenomenon has been observed by using high-temperature confocal laser scanning microscopy. ${ }^{[30,31]}$ Besides, these clusters mainly distributed close to the unmelted alloy piece where the concentrations of $\mathrm{Cr}$ were high, as shown in Figure 10(b). Complex spherical inclusions, which consisted of $\mathrm{FeCr}_{2} \mathrm{O}_{4}$ core and $\mathrm{FeO}_{\mathrm{x}}$ outer layer, were also found. The elemental mapping and line scanning results of these inclusions are shown in Figure 16(a). The possible reason for the formation of these complex inclusions was that $\mathrm{FeO}_{\mathrm{x}}$ precipitated heterogeneously on the $\mathrm{FeCr}_{2} \mathrm{O}_{4}$ core during the solidification. The core may be either single or multi-phase 


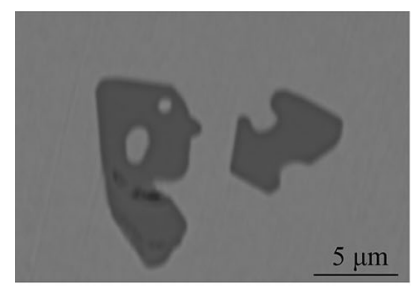

(a)

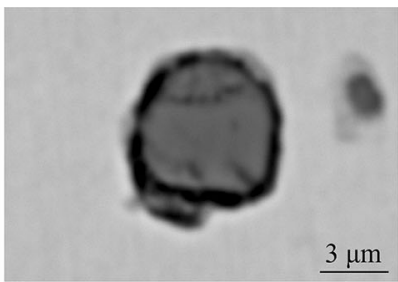

(b)

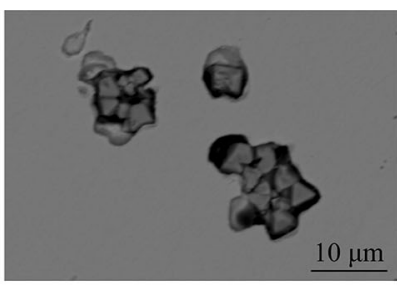

(c)

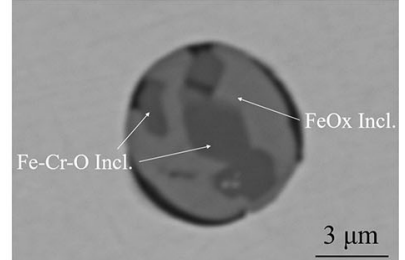

(d)

Fig. 15-(a) through (c) typical $\mathrm{FeCr}_{2} \mathrm{O}_{4}$ inclusions and (d) $\mathrm{FeCr}_{2} \mathrm{O}_{4}+\mathrm{FeO}_{\mathrm{x}}$ inclusion.
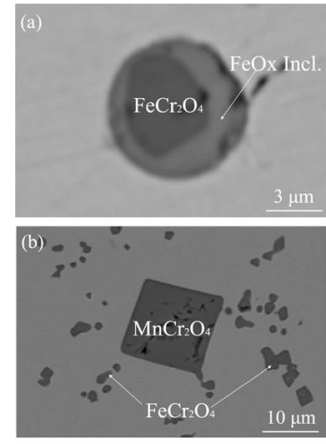
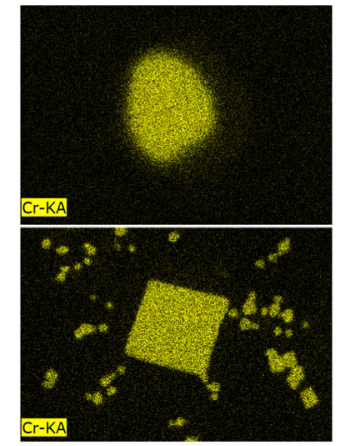
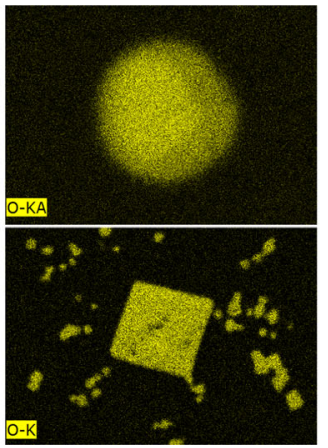
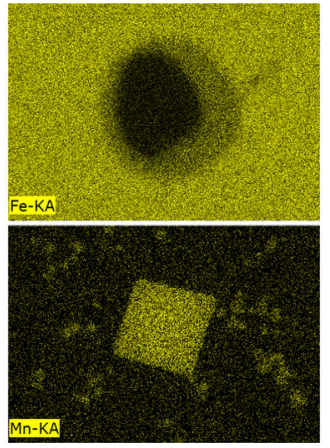

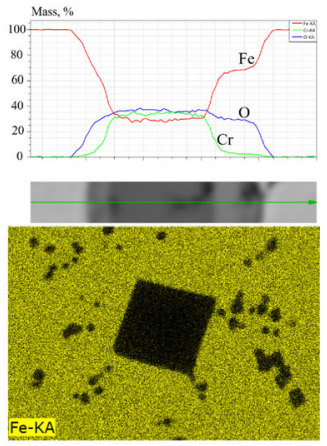

Fig. 16-Elemental mappings and line scanning of $(a) \mathrm{FeCr}_{2} \mathrm{O}_{4}+\mathrm{FeO}_{x}$ and $(b) \mathrm{MnCr}_{2} \mathrm{O}_{4}$ inclusions.

inclusions. However, they were only found in some local areas in the QT samples, where $\mathrm{O}$ was not completely consumed by the formation of $\mathrm{FeCr}_{2} \mathrm{O}_{4}$ inclusions.

Apart from the newly formed $\mathrm{FeCr}_{2} \mathrm{O}_{4}$ inclusions, $\mathrm{MnCr}_{2} \mathrm{O}_{4}$ inclusions originated from $\mathrm{LCFeCr}$ alloys were also found in the diffusion zone and bulk Fe. The elemental mappings of typical $\mathrm{MnCr}_{2} \mathrm{O}_{4}$ inclusion are shown in Figure 16(b). The observed $\mathrm{MnCr}_{2} \mathrm{O}_{4}$ in different parts of the sample have a size range of 6 to $49 \mu \mathrm{m}$. By comparison with their original characteristics in $\mathrm{LCFeCr}$ alloys, it can be concluded that their irregular morphology, size and composition did not change during the experiment. It means that they did not melt or dissolve since their melting point $\left[>2373 \mathrm{~K}\left(>2100^{\circ} \mathrm{C}\right)\right]^{[21]}$ is higher than the experimental temperature. It is, so far, clear that the inclusions from the $\mathrm{LCFeCr}$ alloy can be inherited in the melt at the early stage of dissolution. It should be pointed out that most inclusions were found in the part of the sample where the unmelted alloy piece located.

In addition, some of them with relatively larger sizes were observed in the upper IV part of the QT samples, suggesting that these inclusions float up during the experiment due to their low density $\left(\approx 4930 \mathrm{~kg} \mathrm{~m}^{-3}\right)^{[11]}$ compared to the liquid $\mathrm{Fe}$. This phenomenon also verified the existence of a liquid zone after the melting of the $\mathrm{LCFeCr}$ alloy. During the experiment, no forced intensive stirring occurred. Therefore, the floatation behavior of different inclusions can be estimated by using Stock's law. The calculation results of the floatation distances for $\mathrm{FeCr}_{2} \mathrm{O}_{4}$ and $\mathrm{MnCr}_{2} \mathrm{O}_{4}$ inclusions are shown in Figure 17. As can be seen, the floatation distances for $\mathrm{FeCr}_{2} \mathrm{O}_{4}$ inclusions with the observed size range of 1 to $13 \mu \mathrm{m}$ are less than $2 \mathrm{~mm}$ for the holding time of 10 and 30 seconds. $\mathrm{MnCr}_{2} \mathrm{O}_{4}$ inclusions float up

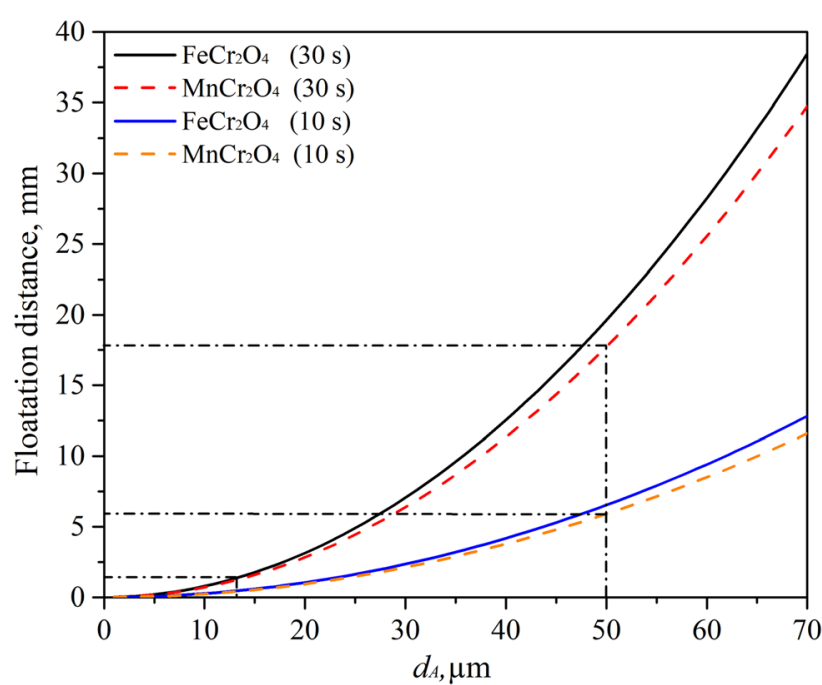

Fig. 17-The floatation distances for $\mathrm{FeCr}_{2} \mathrm{O}_{4}$ and $\mathrm{MnCr}_{2} \mathrm{O}_{4}$ inclusions in the melt.

faster than $\mathrm{FeCr}_{2} \mathrm{O}_{4}$ inclusions under the same size. Moreover, the distance can reach $18 \mathrm{~mm}$ for a $50 \mu \mathrm{m}$ $\mathrm{MnCr}_{2} \mathrm{O}_{4}$ inclusion when the holding time is 30 seconds. This can explain the existence of larger $\mathrm{MnCr}_{2} \mathrm{O}_{4}$ inclusions in the upper part.

\section{E. Dissolution Mechanism of $\mathrm{FeCr}$ Alloys}

The microstructure of the diffusion zone in sample L1 for $\mathrm{LCFeCr}$ alloys is quite similar to those in $\mathrm{HCFeCr}$ alloys. Therefore, the dissolution of $\mathrm{HCFeCr}$ alloys can be treated as an early stage before the alloy melts in the 


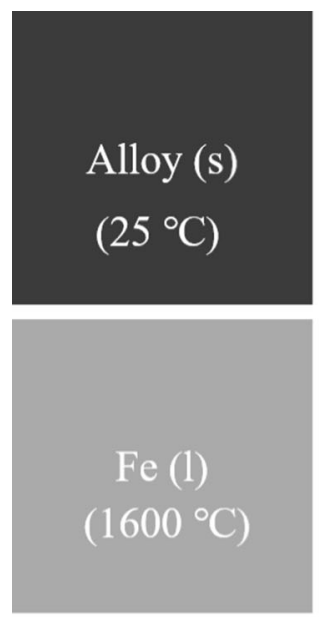

(a)

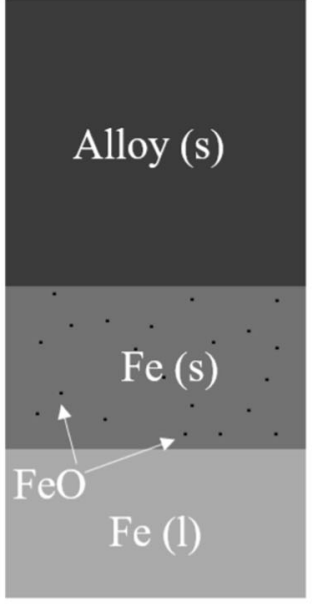

(b)

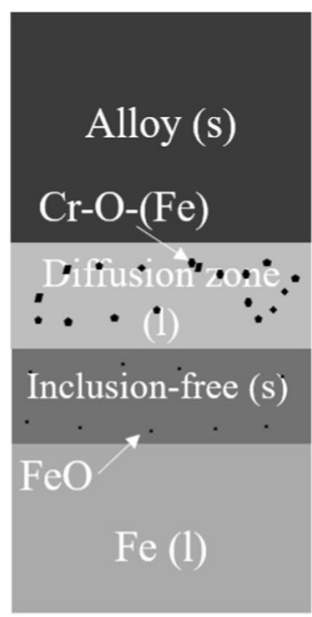

(c)

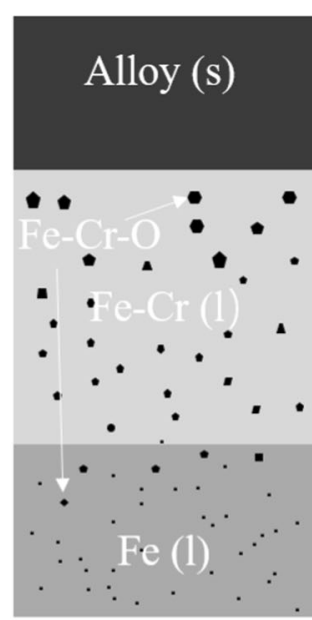

(d)

Fig. 18 - Schematic evolution of the dissolution process of FeCr alloys in liquid $\mathrm{Fe}(a)$ before contact, (b) solid Fe shell form, (c) interdiffusion, and $(d)$ free melting.

case of LCFeCr alloys. Based on the above considerations and observations concerning the microstructure of the diffusion zone, the proposed development mechanism of $\mathrm{Fe}-\mathrm{Cr}$ alloy dissolution process is schematically shown in Figure 18.

(1) Before contact, there is a significant temperature difference between liquid $\mathrm{Fe}\left(1873 \mathrm{~K}, 1600^{\circ} \mathrm{C}\right)$ and solid $\mathrm{FeCr}\left(\sim 298 \mathrm{~K}, \sim 25^{\circ} \mathrm{C}\right)$ (Figure 18(a)). (2) A solid $\mathrm{Fe}$ shell forms around the alloy piece shortly after the contact. This shell grows to a certain maximum thickness until the heat supplied to the surface through convection becomes equal to the heat conducted inside. ${ }^{[32]}$ Due to the fast freezing, small-sized $\mathrm{FeO}$ inclusions $(<1 \mu \mathrm{m})$ are formed inside this shell, which is called the "inclusion-free" zone (Figure 18(b)). (3) As the heat is continuously transferred from the liquid $\mathrm{Fe}$ to the alloy side, the solid $\mathrm{Fe}$ shell starts to melt. Meanwhile, the interdiffusion starts, where $\mathrm{Cr}$ and $\mathrm{C}$ diffuse into the $\mathrm{Fe}$ side and $\mathrm{Fe}$ diffuses into the $\mathrm{FeCr}$ yielding a liquid diffusion zone. Also, $\mathrm{Cr}-\mathrm{O}-(\mathrm{Fe})$ inclusions are formed in different areas in the diffusion zone (Figure 18(c)). Different Fe-Cr phases can form in the diffusion zone during the solidification process depending on the local $\mathrm{Fe}$ and $\mathrm{Cr}$ concentrations and temperatures. (4) With longer holding time, the solid Fe shell and the alloy melt due to the continuous heat supply from the melt and the furnace (Figure 18(d)). With the melting of these zones, the interactions are intensified as the $\mathrm{Fe}, \mathrm{Cr}$, and $\mathrm{O}$ diffusions are enhanced. Except for the diffusion process, a large amount of dissolved $\mathrm{Cr}$ directly reacts with $\mathrm{Fe}$ and dissolved $\mathrm{O}$ to form $\mathrm{Fe}-\mathrm{Cr}-\mathrm{O}$ inclusions in the melt, which also grow with the time. As $\mathrm{FeCr}$ melts, the original inclusions from the alloy piece penetrate through the liquid diffusion zone into the volume of Fe melt. Finally, these original inclusions and inclusions form in the diffusion zone can float up or stay in the melt depending on their densities, sizes and condition of the melt (temperature, stirring rate, etc.). Overall, the melting behavior of ferroalloys depends on many factors such as the superheat, size of the alloy, density, melting point, thermal conductivity of the alloy, melting temperature of steel. More specific studies need to be performed based on these factors in future work.

\section{CONCLUSIONS}

The inclusion characteristics in commercial $\mathrm{HCFeCr}$ and $\mathrm{LCFeCr}$ alloys were investigated. The interactions between these two alloys and liquid $\mathrm{Fe}$ at the early stage of the $\mathrm{FeCr}$ alloy dissolution process were investigated. Moreover, the inclusion formations after the early-stage dissolution of $\mathrm{LCFeCr}$ alloy in liquid $\mathrm{Fe}$ were also studied. The following conclusions could be drawn:

1. Single Cr-Mn-S, CrS, Al-Si-Ti-Cr-Mn-O, TiN inclusions, or combined of them were found in $\mathrm{HCFeCr}$ alloys. Size of different inclusions in this ferroalloy can be varied from 1 up to $23 \mu \mathrm{m}$. Mn-Cr-O, Al-O, and Al-Si-Ca-Mg-O inclusions having size 3 to $50 \mu \mathrm{m}$ were observed in LCFeCr alloys. Size Furthermore, most of the inclusions in $\mathrm{LCFeCr}$ alloys have higher melting temperatures than the steelmaking temperature, while those in $\mathrm{HCFeCr}$ alloys show the opposite tendency.

2. Interdiffusions between solid $\mathrm{FeCr}$ alloy and liquid $\mathrm{Fe}$ resulted in a diffusion zone, which consisted of different $\mathrm{Fe}-\mathrm{Cr}$ phases. In addition, the thickness of the diffusion zone increased with the holding time. The $\mathrm{LCFeCr}$ alloys melt faster than $\mathrm{HCFeCr}$ alloys under the same conditions. An "inclusion-free" zone was observed in the Fe-rich side matrix, which was due to the fast freezing of the Fe shell on the alloy surface.

3. In the early dissolution of $\mathrm{HCFeCr}$ alloys, large numbers of $\mathrm{Cr}-\mathrm{O}-(\mathrm{Fe})$ inclusions were formed in the liquid diffusion zone and $\mathrm{FeO}$ inclusions formed in the bulk Fe only during solidification of metal samples. While in the case of $\mathrm{LCFeCr}$ alloys, plenty of $\mathrm{Fe}-\mathrm{Cr}-\mathrm{O}$ inclusions were found not only in the diffusion zone but also in the bulk Fe when the alloy obviously melted. Their characteristics were closely 
related to the dissolution and melting behavior of the $\mathrm{LCFeCr}$ alloy. In addition, inclusions originated from $\mathrm{LCFeCr}$ alloys were also found without obvious changes in the diffusion zone and bulk Fe.

\section{ACKNOWLEDGMENTS}

Yong Wang acknowledges the financial support from the China Scholarship Council (CSC). Joo Hyun Park acknowledges the LG Yonam Foundation, Korea, for his staying and collaborative research in $\mathrm{KTH}$ Royal Institute of Technology, Sweden.

\section{FUNDING}

Open access funding provided by Royal Institute of Technology.

Open Access This article is licensed under a Creative Commons Attribution 4.0 International License, which permits use, sharing, adaptation, distribution and reproduction in any medium or format, as long as you give appropriate credit to the original author(s) and the source, provide a link to the Creative Commons licence, and indicate if changes were made. The images or other third party material in this article are included in the article's Creative Commons licence, unless indicated otherwise in a credit line to the material. If material is not included in the article's Creative Commons licence and your intended use is not permitted by statutory regulation or exceeds the permitted use, you will need to obtain permission directly from the copyright holder. To view a copy of this licence, visit http://creativecommons. org/licenses/by/4.0/.

\section{REFERENCES}

1. P. Bhonde, A. Ghodgaonkar and R. Angal: Proc. of INFACON $X I$, The eleventh International FerroAlloys Congress, New Delhi, India, 2007, pp. 85-90.

2. T. Hu, H. Liu, B. Liu, L. Dai, L. Zhang and S. Guo: Proc. of 10th Int. Symposium on High-Temperature Metallurgical Processing, San Antonio, 2019, pp. 349-59.

3. M. Pande, M. Guo, S. Devisscher, and B. Blanpain: Ironmak. Steelmak., 2012, vol. 39, pp. 519-29.
4. P. Yan, L. Pandelaers, M. Guo, and B. Blanpain: ISIJ Int., 2014, vol. 54, pp. 1209-17.

5. H. Suito and H. Ohta: ISIJ Int., 2006, vol. 46, pp. 33-41.

6. L. Pandelaers, D. Barrier, P. Gardin, P. Wollants, and B. Blanpain: Metall. Mater. Trans. B, 2013, vol. 44, pp. 561-70.

7. P. Yan, L. Pandelaers, L. Zheng, B. Blanpain, and M. Guo: ISIJ Int., 2015, vol. 55, pp. 1661-68.

8. M.M. Pande, M. Guo, and B. Blanpain: ISIJ Int., 2013, vol. 53, pp. 629-38.

9. Y. Wang, A. Karasev, J.H. Park, and P.G. Jönsson: ISIJ Int., 2020, vol. 61, pp. 209-18.

10. Y. Bi, A. Karasev, and P.G. Jönsson: Ironmak. Steelmak., 2014, vol. 41 , pp. $756-62$

11. Y. Wang, A. Karasev, and P.G. Jönsson: Metals, 2019, vol. 9, p. 687.

12. M. Gasik, A. Panchenko, and A. Salnikov: Metall. Min. Indus., 2011, vol. 3, pp. 1-9.

13. J. Basson and J. Daavittila. High carbon ferrochrome technology. In Handbook of Ferroalloys, Elsevier, 2013; pp. 317-63.

14. J.H. Park and H. Todoroki: ISIJ Int., 2010, vol. 50, pp. 1333-46.

15. J.H. Park and Y. Kang: Steel Res. Int., 2017, vol. 88, p. 1700130.

16. W. Mu, P.G. Jönsson, H. Shibata, and K. Nakajima: Steel Res. Int., 2016, vol. 87, pp. 339-48.

17. H. Kellner, A. Karasev, O. Sundqvist, A. Memarpour, and P.G. Jönsson: Steel Res. Int., 2017, vol. 88, p. 1600024.

18. M. Söder, P. Jönsson, and L. Jonsson: Steel Res. Int., 2004, vol. 75 , pp. $128-38$

19. M. Korpelainen, S.P. Reinikainen, J. Laukkanen, and P. Minkkinen: J. Chemom., 2002, vol. 16, pp. 548-54.

20. K. Oikawa, S.-I. Sumi, and K. Ishida: J. Phase Equilib., 1999, vol. 20 , pp. 215-23.

21. D. Ladutkin, E. Korte, M. Bleymehl, C. Bruch and K.G. Doppler: In Bearing Steel Technologies: 11th Volume, Advances in Steel Technologies for Rolling Bearings, ASTM International: 2017, pp. $48-62$.

22. J.O. Andersson, T. Helander, L. Höglund, P. Shi, and B. Sundman: Calphad, 2002, vol. 26, pp. 273-312.

23. T. Steels: Thermo-Calc Software: Stockholm, Sweden, 2019.

24. F. Su, W. Liu, H. Wang, and Z. Wen: Heat Transfer-Asian Res., 2020, vol. 49, pp. 249-57.

25. H. Doostmohammadi, A. Karasev, and P.G. Jönsson: Steel Res. Int., 2010, vol. 81, pp. 398-406.

26. Y. Wang, A. Karasev, and P.G. Jönsson: Steel Res. Int., 2020, vol. 91, p. 1900669

27. M.A. Van Ende, M. Guo, J. Proost, B. Blanpain, and P. Wollants: ISIJ Int., 2011, vol. 51, pp. 27-34.

28. M.A. Van Ende, M. Guo, J. Proost, B. Blanpain, and P. Wollants: ISIJ Int., 2010, vol. 50, pp. 1552-59.

29. H. Mu, T. Zhang, L. Yang, R.R. Xavier, R.J. Fruehan, and B.A. Webler: Metall. Mater. Trans. B, 2016, vol. 47, pp. 3375-83.

30. W. Mu, N. Dogan, and K.S. Coley: Metall. Mater. Trans. B, 2017, vol. 48 , pp. $2379-88$.

31. W. Mu, N. Dogan, and K.S. Coley: Metall. Mater. Trans. B, 2017, vol. 48, pp. 2092-2103.

32. S. Sanyal, S. Chandra, A. Khullar, and G. Roy: Steel Res. Int., 2006, vol. 77, pp. 542-49.

Publisher's Note Springer Nature remains neutral with regard to jurisdictional claims in published maps and institutional affiliations. 